\title{
Gagne'nin Öğretim Kuramı Temelinde Yapılandırılmış Piyano Derslerinde İşbirlikli Öğrenme Yönteminin İşlevselliği
}

DOI: $10.26466 /$ opus.680488

$*$

\section{Jale Deniz *}

\author{
* Doç. Dr., Marmara Üniversitesi, Atatürk Eğitim Fakültesi, İstanbul/Türkiye \\ E-Posta: jdeniz@marmara.edu.tr \\ ORCID: $\underline{0000-0003-1970-3630}$
}

\section{Öz}

Bu araştırmada, Gagne'nin Öğretim Kuramı temelinde yer alan dokuz öğretim olayına göre planlanarak işbirlikli öğrenme yöntemiyle yapılan piyano derslerinin işleyişinin ve bu yönteme yönelik öğrencilerin görüşlerinin belirlenmesi amaçlanmıştır. Araştırmada, işbirlikli öğrenme yöntemlerinden birlikte öğrenme tekniği kullanılmıştır. Araştırmada nitel araştırma desenlerinden eylem araştırması modeli kullanılmıştır. Araştırmacı bu süreçte hem dersin öğretim elemanı hem de araştırmacı olarak rol oynamıştır. Araştırmanın çalışma grubu, Marmara Üniversitesi Atatürk Ĕ̆itim Fakültesi Müzik Eğitimi Ana Bilim Dalında öğrenim gören 5 kız öğrenciden oluşmuştur. Araştırmada veriler, öz ve akran değerlendirme formları, performans değerlendirme formu, açık uçlu anket soruları ile toplanmıştır. Araştırmadan elde edilen belli başlı sonuçlar şunlardır: (a) Gagne'nin dokuz öğretim olayına göre planlanarak yürütülen piyano derslerinde kullanılan işbirlikli öğrenme yöntemlerinden birlikte öğrenme tekniğinin işleyişi başarıyla gerçekleşmiştir. (b) Piyano derslerinin işbirlikli öğrenme yöntemiyle yürütülmesi, ö̆grencilerin birbirlerinin öğrenmesi için gayret göstererek olumlu bağhllık geliştirmelerine sebep olmuştur. (c) Sürekli paylaşım içinde olan öğrenciler birbirlerini çalışmaya yönelik olarak motive etmişlerdir. (d) Yüz yüze destekleyici etkileşim içinde olmalarını sağlayan bu çalışma yapısı öğrencilerin sürekli iletişim içinde olmaların gerektirdiğinden dolayı sosyal becerilerinde de gelişme sağlamıştır. (e) Derslerde yapılan öz ve akran değerlendirmeleri grup sürecine yansimaya neden olarak kendi öğrenmelerinin yolları ve niteliği üzerine düşünmelerini ve bilişsel öğrenmeleri ile ilgili kararlar almalarını să̆lamıştır.

Anahtar Kelimeler: ̧̇̇birlikli öğrenme, Gagne'nin öğretim kuramı, piyano öğretimi, öğretmen adayı, müzik e ğitimi. 


\title{
The Functionality of Cooperative Learning Methodology in Piano Lessons Designed in Gagne's Instructional Theory
}

\begin{abstract}
The aim of this research is to understand the functionality of piano lessons in a group planned with Gagne's nine events of instruction and conducted with formal cooperative learning work. Students' views toward piano lessons were also examined. The research was conducted as action research model. The researcher played two roles- researcher and the teacher of the group. The study group was consisted of five female students attending Marmara University Atatürk Faculty of Education as prospective music teachers. The main results are (a) Piano lessons planned with Gagne's nine events of instruction and conducted with formal cooperative learning technique have been achieved successfully. (b) Formal cooperative learning technique in piano lessons developed positive interdependence among students as they were responsible of their learning. (c) Students who were in cooperation and sharing their experiences motivated themselves positively to studying and performing. (d) The cooperative learning also improved students' social skills as they have been in a face to face direct interaction during the period of this study. (e) Self and peer evaluations toward their performances through the lessons helped them to improve their way and quality of learning thus they could make decisions on their cognitive learning
\end{abstract}

Keywords: Cooperative learning, Gagne's instructional theory, piano teaching, prospective teacher, music education. 


\section{Giriş}

Gagnénin öğretim kuramı, bilişsel ilkelere dayanan öğretim teorileri içinde en iyi bilinenlerdendir. Bu teori, öğrenmenin olması için gerekli şartlardan bahseder (Schunk, 2009, s.286). Onun teorisi, üç ana bileşen içerir: Öğrenme çıktılarının sınıflaması, her çıktıya ulaşmak için gerekli özel öğrenme koşulları ve öğretimin dokuz olayı. Gagne'ye göre, öğrenme çıktılarının, beş ana kategorisi vardır: Sözel bilgi, zihinsel beceri, biliş stratejileri, tutumlar ve motor beceriler (Driscoll, 2012, s.397-399). Öğrenmeden doğan bu beş çeşit sonuç (çıktı) farklı koşullarda gerçekleşir: İçsel koşullar, ön koşul beceriler ve bilişsel işlem şartlarından oluşur. Dışsal koşullar ise öğrencinin bilişsel süreçlerini destekleyen çevresel uyarıcılardır. İçsel koşullar bellekte bilgi olarak depolanmakta olan öğrencinin mevcut kabiliyetlerinden oluşur. Dışsal koşullar öğrenme sonucunun ve içsel koşulların bir fonksiyonu olarak değişir (Schunk, 2009, s.287). Bilgi işlem kuramını kendine temel alan Gagne'nin öğrenme koşulları, hem içsel olayları (önceden kodlanmış bilgi gibi) hem de dış olayları (kodlamayı kolaylaştırmak için detaylandırma yöntemleri) içerir (Driscoll, 2012, s.397).

Farklı öğrenme çıtıları farklı öğrenme koşulları gerektirir. Öğretimde, ne tür öğrenme koşullarının sunulması gerektiğini planlamak için, çıktı türüne göre, öğrenme hedefleri sınıflandırılmalıdır. Öğretim hedefleri öğretim çıktı türlerine göre sınıflandırıldıklarında, öğretim planlama sistematik olarak devam edebilir (Driscoll, 2012, s.408-409). Gagne öğretimi planlarken dikkate alınacak dış koşulları öğretimin olayları olarak ifade eder. Bu öğretim olayları, bir çalgı çalmayı öğretmek için planlanan çalgı eğitimi derslerini tasarlamada kullanılabilir. Bir çalgı çalmayı öğrenme, müzik bilgisi, müziksel beceriler ve bilişüstü becerilerin edinimini içerir. Çalgı öğretiminde, uzun dönem ve her bir dersin hedeflerini belirleme, öğretmenin ne yapacağını öğrencinin bilmesi, ilerlerken alt hedeflerin belirlenmesi, hedeflere yönelik sürecin izlenmesi, bu izleme sürecinin ışığında gerekli olan alt hedefleri ve hedefleri değiştirmek önemlidir. Hedefler işitsel, bilişsel, teknik veya performans becerileriyle ilgili olabilir (Hallam, 1998, s.254). Çalgi/Piyano öğretimi kapsamında Gagne'nin dokuz öğretim olayını temele alınarak tasarlanan dersler şu dokuz aşamayı içerecektir. Bu aşamalar (1) Dikkat çekme, (2) Öğrenenleri hedeften haberdar etme, (3) Ön öğrenmelerin hatırlanmasının uyarılması, (4) Uyaranı sunmak, (5) Öğrenme rehberliği sağla- 
ma, (6) Performansı ortaya çıarma, (7) Dönüt verme, (8) Performansı değerlendirme, (9) Tutma ve transferi artırma olarak ifade edilmektedir.

(1) Dikkat çekme, öğretimde olması gereken ilk olaydır. Bu aşamada öğrenci öğrenilmesi gereken materyale uygun uyarıcılara odaklanır (görselişitsel, yazılı gereçler, öğretmenin model olduğu davranışlar) (Schunk, 2009, s.288). Dikkati çekme, öğrencilerin dikkatini yeniden kazanmak için, bir ders boyunca, çeşitli şekillerde tekrarlanabilen, bazı tür uyarıcı değişiklikleri tarafından yapılır (Driscoll, 2012, s.416). Hallam (1998, s.257) öğretmenlerin derse, dersin hedeflerini, amacını ve yapısını açıklayarak başlamalarını, ders boyunca anlamlı bir hareketle herkesi meşgul etmelerini, dersi tutarlı bir bütünlükle yapmaların, önceden bilinen materyal ve yeni kavramlar, fikirler ve müzik arasında bir denge sağlamalarını mümkün olan her yerde göstermeleri gerektiğini belirtmektedir. Ayrıca öğretmenin uzun bir zaman aralığını kapsayan konuşmalardan kaçınmalarını, kayıtlar, videolar, kitaplar gibi dış uyarıcıları, güncel olayları kullanmalarını ve öğrencilerin ilgilerini sürdürmeyi denemelerini de vurgulamaktadır.

Belli bir çalgıya bağlılık, motivasyonu devam ettirmede önem taşır (Hallam, 2008, s.91). Öğrenci genellikle çalgı çalmayı öğrenmeye başlamak için gönüllü olduğunda çalgı müziğinde ön bir ilginin varlı̆ından söz edilebilir. Ancak bu ilgi sürdürülmeye ihtiyaç duyar. Muhtemelen sahiplenme [benimseme] burada bir anahtar kelimedir. Bireyler, öğrendikleri şeyin onların olduğunu, bunun özel bir çalgı olup olmadığını, bir kariyer edinme planlarının olup olmadığını veya sorumluluk alıp almayacakların hissettikleri zaman hakiki olarak motive olurlar. Öğrencilerin sahiplenmesi [benimseme] tercih yapmalarına izin verilerek teşvik edilebilir. Böylece öğretmenler, öğrencileri öğrendikleri müzik, öğrendikleri parçaların zorluk seviyesi (gerilim isteyip istemedikleri), smavlara girmeyi isteyip istemedikleri (eğer istiyorlarsa ne zaman girecekleri), konsere çıkıp çıkmayacakları (eğer çıkacaklarsa bireysel olarak mı yoksa grupla mı çıkacakları) hakkındaki kararları almada işin içine almayı denemeliler. Aynı zamanda öğretmenler, şaşırtarak, aykırı, çelişkili, tartışmalı uyarıcı durumlar yaratarak öğrenmeye ilgi çekebilirler (Hallam, 1998, s.99).

(2) Öğrenenleri hedeften haberdar etme, öğrenenlere, öğrenmeden sonra ne yapacaklarını söylemedir. Bütün öğrencilerin, herhangi bir öğretim durumunda, ne öğrenmeleri gerektiği hakkında beklentiler geliştireceğine dikkat edilmesi gerekir. Beklentiler, öğrencilerin, öğretimden ya da beklenen öğ- 
renme çıtıları gösterimlerinden sonra, ne yapabileceklerini ifade eden, öğretim hedeflerine dair basit açıklamalarla kolaylıkla oluşturulacaktır (Driscoll, 2012, s.417). Öğrencinin [haberdar olduğu hedefler doğrultusunda] beklentisi öğrenciyi hedefe doğru yönlendirir (Shunk, 2009, s.288).

Çalgı öğretiminde, öğretmenin son performans hedefi doğrultusunda bütünü oluşturan alt hedefleri ortaya koyması gerekir. Son performans hedefine ulaşabilme çok sayıda alt hedefin gerçekleşmesiyle mümkün olabilir. Öğrenciler alt hedefleri başarmak için uğraşır, daha sonra bütünden parçalara bölünmüş hedefleri birleştirebilmek için yardıma ihtiyaç duyarlar. Bu noktada öğretmen öğrencinin başarması için uygun olan şeyi belirlemeye ihtiyaç duyar. Bu ders sırasında deneme yanılma yoluyla da kurgulanabilir. Eğer başarı elde edilmezse daha küçük hedefler belirlenir. Görev bileşenlerinde ustalaştığı zaman birleştirme süreci başlayabilir (Hallam, 1998, s.126).

(3) Ön öğrenmelerin hatırlanmasının uyarılması, daha önce öğrenilmiş bilgilerin ya da becerilerin hatırlanmasını istemedir. Yeni öğrenmeler, büyük ölçüde daha önce öğrenilmiş olan bilgilere bağlı olmasına rağmen, öğrenciler yeni bir öğrenme görevi ile karşılaştıklarında, eski bilgileri her zaman hatırlamazlar ve ilgili bilgileri kullanmazlar. Bilgi transferi, yani daha önce öğrenilmiş bir şeyin yeni bir bağlama uygulanması, her yaşta zordur. Bu yüzden kodlama ve transfere öğrencileri hazırlamak için, eğitmenlerin ilgili ve önkoşul bilgilerle onlara yardım etmesi gerekir (Driscoll, 2012, s.417).

(4) Uyaranı sunma, yeni kavram veya kuralla ilgili örnek verilmesi, ayırt edici özelliklerle içeriğin gösterilmesidir. Motor beceriler veya biliş strateji için uyarıcı sunmak, istenen çıtının gösteriminden veya sözel talimatlar verilmesinden oluşur. Uyaranın sunumunun, seçici algı ve modeli tanıma işlemini kolaylaştırması için, istenen çıtıların temel öğelerini ya da ayırıcı özelliklerini vurgulaması gerekir (Drsicoll, 2012, s.419).

Öğrencilerin öğrenecekleri parçanın kulağa nasıl geldiğini bilmeleri gerekir. Bu onlara toplam hedefteki son noktayı gösterir. Öğrenci çalacağı parçanın işitsel resmini (temsilini) nasıl ortaya koyacağını öğrenmeye ihtiyaç duyar. Eğer parçanın seslendirmesini bilmeden parçayı öğrenmeye başlarsa hataları belirleyemeyecektir. Eğer uygun içsel işitsel bir temsil oluştururlarsa, bu şablonla yaptıklarını eşleştirebilirler. Bu ritim duyusunu ve doğru entonasyon geliştirmeye yardımcı olur. Öğrenciye şablon oluşturma, CD kayıtları ya da öğrenciye müziği çalarak sağlanabilir. Hallam (1998, s.127) çalg1 öğretiminde öğretmenin çalarak ya da kayıtlardan dinleterek 
öğrencilerin karşılaştırmalar yapabilmesi için şablon sağlaması gerektiğini belirtmiştir.

(5) Öğrenme rehberliği sağlama, yeni bilginin belleğe transfer edildiği süreçtir. Öğretim aktiviteleri, anlamlı bir şekilde uzun süreli belleğe, ne öğretilmesi gerektiğinin girişini teşvik etmelidir. Ne kadar öğrenme rehberliği sağlanacağı, öğrenenlerin yeteneğini ve gelişmişliğini, öğretim için mevcut zaman miktarını ve birden fazla öğrenme hedeflerinin varlığın kapsayan çeşitli faktörlere bağlıdır (Driscoll, 2012, s.419).

Öğrenciye bu rehberlik sağlanırken örnekleme yapmak gerekir. Örnekleme şablon sağlamada etkili bir yoldur. Öğretmen istenilen parçanın ya da tekniğin örneğini gösterir. Öğrenci gözlemler ve performansı taklit etmeye çalışır. Örnek gösterme gerçek bir performans şeklinde olmak zorunda değildir. Öğretmen, öğrencilerin kopyalamasını istediği özel noktaları resmetmek için mırıldanarak, el vurarak ya da fiziksel hareketlerle işitsel modellemeler kullanabilir. Modelleme beceri ediniminde çok önemlidir. Çalgı öğrenmede modellemenin olumlu etkileri araştırmalarla açıkça ortaya konmuştur. Ancak bulgular, öğretmenlerin derslerde modellemeye daha az ve konuşmaya daha çok zaman ayırdıklarını göstermektedir. Modellemenin önemi, öğrencinin ulaştığı aşamaya bağlıdır. Modelleme, ilk aşamalarda, öğrencilerin kendi çalmalarını bir şablonla eşleştirme fırsatı yaratarak öğrenmeyi artırırken, ileri aşamalarda taklit yorumların ortaya çıkmasına sebep olabilir (Hallam, 1998, s.127).

(6) Performansı ortaya çıkarma, öğrenenden yapmasını istemedir. Öğrencilere, kendi öğrenmelerini, kendi kendilerine, öğretmenleriyle ve diğerleriyle pekiştirmeleri için olanak sağlar. Performansı geliştirmenin amacı, öğrenenlerin ne öğrendiklerini göstermeleridir. Bu olay, hala hataları düzeltmenin devam ettiği ve performansın hala geliştirildiği varsayımıyla, öğrencinin ilerleme göstermesine bir imkân sağlar (Driscoll, 2012, s.420).

Bir parçayı öğrenmenin ilk aşamalarında öğretmen, öğrenciye işitsel bir iskelet sağlayabilir. Bu öğrenciyle birlikte çalarak ya da söyleyerek sağlanabilir. Öğretmen aynı çalgıyı ya da farklı bir çalgıyı, söylemeyi ya da çalmayı tercih edebilir, piyanoyla eşlik edebilir, melodiyi destekleyebilir. Öğrenci daha akıcı çalmaya başladığı zaman, öğretmen bazı cümleleri atlayabilir, zor olan yerlerde katılabilir ya da liderliği öğrenciye bırakmak için daha hafif çalabilir. Bu destek öğrenciye güven verir, müziğin işitsel sunumunu geliştirmeye olanak verir, devam etmeleri için öğrencileri mecbur bırakır. 
Bu strateji aynı zamanda deşifre becerilerini geliştirmede faydalı bir yoldur (Hallam, 1998, s.127).

(7) Dönüt verme, öğrenenlere, performansları hakkında, ne yapabildiklerini göstermek ve bilgilendirmek içindir (Driscoll, 2012, s.420). Performansı ortaya çıkarmak için öğrenenden yapması istenir ve bu aşamada öğrencinin verdiği karşılığın doğruluğunu saptamak ve gerekirse düzeltme yapmak üzere geribildirim verilir (Schunk, 2009, s.289). Çalgı çalmayı öğretirken, müzikteki yanlışlar, entonasyon, ton, teknik, yorum, iletişim gibi boyutlar hakkında geribildirim verilir. Ancak geribildirim vermeye önce öğrencinin başardığı şeylerden başlamak gerekir. Düzeltmelere yavaş yavaş geçilmeli ve pozitif terimlerle yapıcı geri bildirim sağlanmalıdır (Hallam, 1998, s.128).

(8) Performansı değerlendirme, öğrenenlerin, bilgilerini gösterme ve düzeltme imkânlarına sahip olduktan sonra yapılır. Bu olay genellikle ünite veya bölüm testleri projeler, beceri sergileme ve benzerleri aracilığıla uygulanur (Driscoll, 2012, s.421).

(9) Tutma ve transferi artıracak öğretim aktiviteleri, önceki aşamalarda, sık sık öğretimin içine yerleştirilir. Öğrenme rehberliği sağlama, aralıklı değerlendirmeler zihinsel ve motor becerilerin tutulmasını kolaylaştırır (Driscoll, 2012, s.421). Bu aşama, öğrencilere becerilerini farklı içerikle ve farklı şartlarda tekrarlama imkânı sağlar (Schunk, 2009, s.289). Hallam (1998, s.129) da çalg1 öğretiminde, edinilen her yeni becerinin otomatikleşebilmesi için alıştırma yapılması gerektiğini belirtmiştir. Bu aynı parçayı defalarca aynı yolla çalmak demek değildir. Aynı parçalar, değişik hızlarda ve gürlükte çalışılabilir. Ayrıca bir grup içinde çalma firsatı sağlayarak öğrenenlerin birbirlerini izleyerek edinilen yeni becerilerin tekrarlaması sağlanabilir.

Etkili bir öğretim için, öğretimin bu dokuz olayının yanında, işbirlikçi öğrenme yapıları kullanılarak, öğrenciler birbirlerine hem öğrenme rehberliği hem de dönüt sağlayabilirler (Driscoll, 2012, s.422).

İşbirlikli öğrenme, günümüzde keşfe dayalı öğrenmeyi yaymak ve öğrenmeyi sosyal bir aktivite olarak gerçekleştirmek için giderek yayılmaktadır (Efe ve diğerleri, 2008, s.2). İşbirlikli öğrenme, öğrenmeyi en üst seviyede gerçekleştirmek amacı ile değişik yetenekleri olan öğrencilerin küçük gruplar halinde çalışarak ortak bir hedefe ulaşmaların ifade eder (Johnson ve Johnson, 1994 ve 1999; Akt: Efe ve diğerleri, 2008, s.2). 
İşbirliğine dayalı öğrenme beş temel unsuru içerir (Saban, 2014, s.190): Bunlar, olumlu bağlılık, yüz yüze destekleyici etkileşim, bireysel sorumluluk, kişilerarası veya sosyal beceriler ve grup sürecine yansımadır.

Olumlu bağglllk. İşbirlikli çalışma gereği öğrencilerden olumlu bağlılık geliştirmeleri beklenir. Olumlu bağlllık gruptaki bir üyenin kişisel çabalarının yalnızca bu üyenin kendisi için değil, gruptaki bütün üyeler için faydalı olacağını kavramaları, fark etmeleri ve bilincinde olmaları gerekir. Üyelerden birinin başarısı ancak gruptaki herkesin başarısı söz konusu olduğunda mümkün olabilir (Saban, 2014, s.191). Grup üyelerinin, başarılı olabilmek için grubun başarılı olması gerektiğine inanmaları gerekir. Bu koşul işbirlikli ödül yapısı ve işbirlikli iş yapısıyla elde edilir. İşbirlikli ödül yapısı, grup üyelerinin grup amaçları doğrultusunda grup ürünü ortaya koymalarını ve grup halinde ödüllendirilmelerini gerektirir. İşbirlikli iş yapısı ise, grup üyelerinin bir işi bitirmek amacıyla çabalarının birleştirilmesinin özendirildiği ya da gerekli bulunduğu durumlardır (Ün Açıkgöz, 2008, s.174). İşbirliğini sağlamada grup ödülünün verilmesi, ödül bağımlılı̆̆ıdır. Ancak amaç bağımlılığı olmadan ödül bağımlılığının olması imkânsızdır. Olumlu bağlılık bireylerin ortak amaç ve ödül için çabalarını birleştirecek bir durum yaratır. Olumlu ürün bağımlılığı, grup üyelerinin eğer birlikte çalışırlarsa başarabileceklerine inanmaları anlamındaki amaç bağımlılığını ve ortak ürüne dayalı olarak verilen tek tip ödül anlamındaki ödül bağımlılığını içerir. Ayrıca olumlu bağımlılık, kişisel sorumluluk ve değerlendirilebilirlik duyguları yaratacağından, sorumluluktan kaçma, yardım etmek istememe gibi durumları önleyebilir (Ün Açıkgöz, 2008, s.175).

Bireysel sorumluluk, gruptaki her bireyin daha iyi performans gösterebilmesi için herkesin performansının değerlendirilip, sonuçlarının hem gruba hem de üyenin kendisine geri verildiği durumlarda ortaya çıkar (Saban, 2014, s.194).

Yüz yüze destekleyici etkileşim, grup üyelerinin birbirlerinin çabasını özendirmesi ve kolaylaştırmasıdır. Öğrenciler bunu yardım etme, dönüt verme, güvenme, yapılanları tartışma v.b. davranışlarla gerçekleştirirler (Ün Açkgöz, 2008, s.176).

İşbirliğine dayalı gruplarda öğrenciler, hem akademik konuyu, hem de grubun bir ekip ruhu ile çalışmasını mümkün kılan kişilerarası veya sosyal becerileri öğrenmekle yükümlüdür. Dolayısı ile işbirlikçi öğrenmenin başarısı için liderlik, karar verme, iletişim, karşılıklı güveni inşa etmek ve herhan- 
gi bir anlaşmazlığ çözmek gibi beceriler öğretmen tarafından amaçlı ve açk bir şekilde öğrencilere kazandırılmalıdır (Saban, 2014, s.195).

Grup sürecine yansıma (grup sürecinin değerlendirilmesi), grup etkinliğinin sonunda, grup üyelerinin hangi davranışlarının katkı getirip getirmediğinin, hangi davranışların sürmesi, hangilerinin değişmesi gerektiğinin saptanmasıdır (Ün Açıkgöz, 2008, s.176). Bu değerlendirme, üyeler arasındaki iyi çalışma ilişkilerini sürdürmelerini, kendi bireysel katkılarına yönelik gruptan geribildirim almalarının garantisini, kendi bilişsel öğrenmeleri üzerinde düşünmelerini ve pozitif davranışlarını pekiştirmek için etkili bir mekanizma sağlar (Saban, 2014, s.196).

İşbirlikli öğrenme yönteminin kullanımda çeşitli tekniklerin geliştirildiği görülmektedir. Bu bağlamda, birlikte öğrenme, öğrenci takımları başarı bölümleri, takım-oyun-turnuva, birleştirme, işbirliği-işbirliği, birlikte soralım birlikte öğrenelim, renkli kodlanmış işbirlikli kartları vb. tekniklerden söz edilebilir (Efe ve diğerleri, 2008; Ün Açıkgöz, 2008). Örneğin bu çalışma kapsamında yararlanılan birlikte öğrenme tekniği, öğrencilerin belli bir süre içinde birlikte çalışıp, ortak hedeflere ulaştıkları ve belirli ödevleri, işleri beraber yaptıkları grup çalışmasıdır. Bu teknikte, dersler, sınıf uygulamaları vb. işbirlikli olup, tüm etkinlikler, pozitif bağımlığı, yüz yüze teşvik edici iletişimi, bireysel sorumluluğu, sosyal beceri ve grup çalışma sürekliliğini sağlar olmalıdır (Efe ve diğerleri, 2008, s.45).

Araştırmalara dayalı olarak, işbirlikli öğrenme yönteminin diğer öğrenme yöntemleri ile karşılaştırılması sonucunda ortaya çıkan sonuçlar şu şekildedir: (1) Her başarı seviyesindeki öğrenci için daha yüksek başarı düzeyine ve daha ileri yaratıcılık becerilerine sahip olmayı içerir. Bilgileri uzun süre bellekte tutabilme, içsel motivasyonu sürdürebilme, başarı motivasyonu, görev için harcanan zaman, üst düzey akıl yürütme ve eleştirel düşünme becerilerini kapsar. (2) Öğrenciler arasında daha olumlu ilişkiler kurulur. Ekip halinde birlikte çalışma, daha bağlı ilişkiler, kişisel ve akademik sosyal destek, farklılıklara saygı ve uyum gibi konuları içerir. (3) Daha iyi bir psikolojik durum sağlar. Genel psikolojik uyum, güçlü ego, sosyal gelişim, sosyal yetkinlik, öz saygı, öz kimlik, sıkıntı ve stresle başa çıkabilme gibi konuları kapsar. İşbirlikli öğrenme yönteminin bu başlıklar gibi önemli çıktıları, yöntemi diğer yöntemlerden ayırmakta ve yöntemin önemini artırmaktadır (Johnson, Johnson, Holubec, 2016, s.1-3). 
Çalgı öğretimi ise genellikle bireysel olarak yapılır. Ancak çalg1 öğretimine yönelik olarak yapılan uygulamalara bakıldığında bireysel öğretim uygulamalarının yanı sıra grupla öğretime doğru yönelimlerin olduğu görülmektedir. Bu yönelimlere örnek olarak grupla piyano öğretimi verilebilir (Hahn, 2019; Özalp ve Özdemir, 2019; Tecimer Kasap, 2005). Grup piyano öğretimi, ilk olarak 1920'li ve 1930'lu yıllardan itibaren yapılmaya başlanmıştır. Elektronik klavyelerin ortaya çıkmasıyla, grup dersleri yaygınlaşmıştır (Hallam, 1998, s.253). Ülkemizde yapılan araştırmalar incelendiğinde, özellikle son yıllarda grupla yapılan piyano öğretiminin müzik öğretmeni adayları ve konservatuvar öğrencileri seviyesinde uygulamalarının olduğu görülmektedir. Aydınlı ve Tecimer (2013) eğitim fakültesi müzik eğitimi öğrencileriyle yaptığı deneysel çalışma sonucunda, grupla yapılan piyano öğretiminin öğrencilerin piyanoda eşlikleme ve transpoze becerilerini geliştirmede, bireysel piyano eğitimi alanlara göre daha başarılı olduğunu tespit etmiştir. Lehimler ve Batıbay (2018) eğitim fakültesi müzik eğitimi öğrencileriyle yaptıkları deneysel çalışma sonucunda, grupla piyano öğretimi yapılan öğrencilerin artistik ve işlevsel piyano becerilerinin bireysel piyano öğretimi gören kontrol grubuna göre anlamlı seviyede daha iyi olduğunu bulmuştur. Acar (2019) ise müzik teknolojilerinin başlangıç seviyesinde grup piyano eğitiminde kullanılabilirliğine yönelik olarak yürüttüğü bir eylem araştırmasında programın işlevsel olarak başarılı olduğunu ortaya koymuştur.

Çalgı öğretiminde bireysel ya da grup öğretiminin yapılması karşılıklı olarak birbirlerini destekleyici etkinliklerdir. Grupla çalgı öğrenimini teşvik etmek, müzikal standartlara erişmede ve müzikal gelişmeyi sağlamada yarar sağlar (Ley, 2004, s. 9).

Hallam (1998, s.253) çalgı öğretiminin grupla yapılmasının olası avantajlarını yedi madde altında açklamıştır. Buna göre (1) grup öğretimi öğretmen ve öğrenciler için daha fazla uyarıcı olabilir, (2) alternatif yöntem ve stratejileri göstermek için daha çok fursat sağlayabilir, (3) müzikal ve teknik eleştirel değerlendirme için daha çok fırsat sağlayabilir, (4) öğrencileri bağımsız öğrenmeye teşvik edebilir, (5) daha eğlenceli olabilir, (6) gerginliğin üstesinden gelmek için resmi olmayan sunum fırsatları sağlayabilir; (7) çekingenlerin diğerlerine çalarken kendilerini daha az ketlenmiş hissetmelerini sağlayabilir. 
Çalg1 öğretiminde, usta çırak ilişkilerinin geleneksel olarak öğretime yön verdiği ifade edilen birçok kaynak bulunmaktadır (Çelik Nayır, 2018; Haşhaş, 2016; İzgi, Yazıcı ve Kılıç, 2016). Bununla birlikte günümüzde gerek genel gerekse özel (müzik) çağdaş öğretim yaklaşımlarının (model, yöntem vb.) gelişmesi çalgı öğretimi alanına yeni ufuklar açmaktadır. Ancak ortaya konan bu öğretim yaklaşımlarının etkililiğinin alana özgü olarak planlanarak somutlaştırılması gerekmektedir. Örneğin, Gagne'nin öğretim kuramı, dokuz öğretim olayı ile öğretme sürecine genel bir çerçeve sunmuştur. Diğer yandan yapılandırmacı öğrenme anlayışının öğretim programlarında yer alarak yaygınlaşmasıyla işbirlikli öğrenmenin önemi artmıştır. Gagne'nin dokuz öğretim olayının işbirlikli öğrenme yapılarında nasıl uygulanabileceğini ortaya koymak bu araştırmanın problemini oluşturmaktadır.

Bu problem doğrultusunda araştırmada, işbirlikli öğrenme yöntemlerinden birlikte öğrenme tekniği kullanılarak ve Gagne'nin dokuz öğretim olayına göre planlanarak yapılan piyano derslerinin işleyişinin ve bu yönteme yönelik öğrencilerin görüşlerinin belirlenmesi amaçlanmıştır. Bu genel amaç doğrultusunda piyano derslerinin işleyişinin belirlenmesi için (1) Öğrencilerin öz değerlendirmeleri nasıldır?; (2) Öğrencilerin akranlarını değerlendirmeleri nasıldır?; (3) Öğrencilerin, öğretim elemanı ve komisyon tarafından yapılan son performans değerlendirmeleri nasıldır?; (4) Piyano derslerinde kullanılan işbirlikli öğrenme yönteminin başlıca koşullarına (olumlu bağlılık, bireysel sorumluluk, yüz yüze destekleyici etkileşim, sosyal beceriler, grup sürecine yansıma) yönelik öğrencilerin görüşleri nelerdir? sorularına cevap aranmıştır.

\section{Yöntem}

Araştırmada nitel araştırma desenlerinden eylem araştırması modeli kullanılmıştır. Eylem araştırması, bizzat uygulamanın içinde bulunan bir uygulayıcını kendisinin veya bir araştırmacı ile birlikte gerçekleştirdiği ve uygulama sürecine ilişkin sorunların ortaya çıkarılması, ortaya çıkmış bir sorunun anlaşılması ve çözümler üretilmesine yönelik sistematik veri toplamaya ve analiz etmeye yönelik bir araştırma yaklaşımıdır (Yıldırım ve Şimşek, 2013, s.333). Bu araştırmada araştırmacı piyano derslerinde ders öğretmeni olarak dersi yürütmüş ve ayrıca araştırmanın da uygulayıcısı olmuştur. Gagne'nin öğretim kuramı temelindeki dokuz öğretim olayı göz önüne 
alınarak planlanan grupla yapılan piyano derslerinde, işbirlikli bir öğrenme yaklaşımı yürütülerek bu grup çalışmasının işleyişi ve başarıdaki etkisi ortaya koyulmuş ve değerlendirilmiştir.

Eylem araştırması, bir problem ya da araştırma konusunun tanımlanmaS1, kurgulanması, veri toplamak için plan yapılması, veri toplamaya başlanması ve analiz edilmesi, veriyi toplarken problemlerin ya da soruların değişmesine izin verilmesi, verinin analiz edilmesi ve düzenlenmesi, verinin raporlaştırılması, yarg1 ve önerilerin yapılması, bir eylem planının yapılmaS1, planın uygulanması ve değerlendirilmesi adımların içerir (Johnson, 2015, $\mathrm{s}, 56)$. Araştırmada, eylem araştırması adımları doğrultusunda, genelde bireysel olarak yapılan piyano derslerinin, işbirlikli öğrenme yöntemiyle grup olarak yapıldığında ortaya çıkan değişiklik ve sorunların tespit edilmesine, tartı̧ma ve önerilerle bu yeni duruma yönelik düzenlemeler ve değerlendirmeler yapılmasına gayret edilmiştir.

\section{Uygulama Süreci}

Grup olarak çalışılarak bireysel performansın ortaya konulması için ikişer ders saatinden oluşan 8 haftalık bir çalışma yürütülmüştür. Dersler Gagne'nin öğretim kuramı temelinde, onun dokuz öğretim olayı göz önüne alınarak planlanmıştır. Aynı zamanda işbirlikli öğrenme yapıları kullanılarak, öğrencilerin birbirlerine hem öğrenme rehberliği hem de dönüt sağlamalarına olanak verilmiştir.

\section{Derslerdeki İşbirlikli Öğrenme Sürecine İlişkin Uygulamalar}

Ders öğretim elemanı ilk derste öğrencilere öncelikle işbirlikli öğretimin kullanılacağı bir grupla piyano dersi planladığını bildirmiştir. Ders içi ve ders dışı süreçlerde işbirlikli öğrenme tekniklerinden olan ve Johnson ve Johnson (1991) tarafından geliştirilen "birlikte öğrenme" tekniği kullanılmıştır (Akt. Ün Açıkgöz, 2008, s.177). Gruba öncelikle işbirlikli öğrenme yönteminin ve birlikte öğrenme tekniğinin ne olduğu açıklanmıştır. Dersin amaçları doğrultusunda, öğrencilere birlikte çalışıp, birbirlerinin öğrenmesini en üst seviyeye çekip ortak başarıya ulaşacakları, bildirilmiştir. Yani gruptakilerin bireysel başarısının grubu başarıya taşıyacağı; böylece grup ödülünü elde edecekleri belirtilmiştir. Dolayısıyla olumlu bağımlılık sağlamak için, 
gruptakiler ortak amaç ve ödüle ulaşmaya motive edilmişlerdir. Ders süreci 8 haftada tamamlanmıştır. Her bir hafta için 50'şer dakikalık iki dersten oluşan ders oturumları yapılmıştır. Grup 5 öğrenciden oluşmuştur. Her hafta birinci ders öğrenciler 2 gruba ayrılmış ve bir grup 2 kişi diğer grup ise 3 kişi olarak birbirlerini dinlemiş ve geribildirimlerde bulunmuşlardır. Ders öğretim elemanı ise gruplara katılarak gerektiğinde rehberlik etmiştir. İkinci ders ise iki grup tekrar bir araya gelmiş ve öğretmen rehberliğinde ders yapılmıştır. Her bir öğrenci sırayla parçalarını çalmış, ders öğretim elemanı ve diğer öğrencilerden geribildirim almıştır. Ders sonunda öğrenciler öz değerlendirme formlarına kendilerini değerlendirmişlerdir. Öğrenciler ders sonunda eksiklerini, kendi kendine çalışmalarında nelere odaklanacaklarını gözden geçirmişlerdir. Hafta içi ise herkes bir çalışma arkadaşından sorumludur ve çalışma arkadaşı ile çalışmalarını çalışma çizelgesine işaretlemiştir. Grup bağımlılığını sağlamak için öğrencilere çeşitli roller verilmiştir (Akt. Ün Açıkgöz, 2008, s.178). Buse, özetleyici; Hale, denetleyici; Sena, özendirici; Kumru, gözlemci; Güliz, bağ kurucu rolünü üstlenmiştir. Rollerin seçimine öğrenciler kendileri karar vermişlerdir.

\section{Derslerdeki Öğretim Olaylarna İlişkin Uygulamalar}

Gagne'nin öğretim kuramına dayalı dokuz öğretim olayı, piyano öğretiminde derslerin planlanmasında kullanılmıştır. Bu kapsamda her derste belirtilen dokuz öğretim olayı gelinen seviyeye, ihtiyaca ve yapılan çalışmaların içeriğine göre düzenlenerek gerçekleştirilmiştir.

Ders öğretim elemanı derse dikkat çekme amacıyla, çalışılacak parçalara yönelik öğrencilere tanıtıcı bilgi vermiştir. Ders süreçlerinin tamamlanması sonunda ortaya çıkarılması beklenen ve öğrenciler tarafından daha önce çalışılmamış olan iki parça son performans görevi olarak belirlenmiştir. Bu parçalar, William Alwyn'in 'The Sun is Setting' isimli parçası (ABRSM, 2012a) ve Victor-Alphonse Duvernoy'un huzlı pasajlarda her iki elin parmaklarında eşit dokunuş ve dayanıklılık elde etmeyi sağlayan ritmik do majör gamlardan oluşan 'Do Majör etüdü'dür (Bradley, t.y.). Derste önce çalışılan parça olan Duvernoy'un etüdü ve daha sonra Alwyn'nin parçası hakkında bilgi verilmiştir. Başlangıçta çok fazla sözel açıklamanın sıkıcı olacağı düşünüldügünnden açıklamalar bu esnada kısa tutulmuş ve daha ayrıntılı açıklama uygulama anına bırakılmıştır. 
$\mathrm{Bu}$ açıklamanın ardından öğrencileri hedeften haberdar etme amacıyla, beklentiler açıklanmıştır. Yukarıda belirtilen son performans hedefi olan parçalara göre belirlenen alt hedefler; teknik becerilerin gelişimi (duruşoturuş-beden dengesi, el-parmak-kol hareketleri, hızlı pasajlarda dayanıklılık elde etme, tuşeye her iki elle eşit dokunuş, artikülasyon, ifadeli bir ses kalitesi geliştirme); müzikal becerilerin gelişimi (ifadeli çalma, sesi yansıtabilme, ses üzerinde denetim, anlamı ifade etme); zihinsel becerilerin gelişimi (tonun, nota değerlerinin ve seslerin doğru okunması, tempo bütünlüğü, parçalardaki armoninin ve müzik biçiminin kavranması); diğerlerine sunum becerilerinin gelişimi; öğrenme becerilerinin gelişimi (tüm ders sürecinde bağımsız olarak öğrenme, izleme ve değerlendirmenin gelişimi) olarak belirlenmiştir.

Daha sonra, öğrencilerden önce öğrenilmiş bilgilerin ve becerilerin hatırlanması istenmiştir. Bunlar piyanoda duruş, oturuş, el çatısı, parmakların üç oynar kemiğinin çökmemesi, bileğin esnek ve serbest olması, dizilerde baş parmak geçişi (baş parmağın üstten ve alttan geçişi sırasında eli döndürmeden o anda kolu hafifçe yana doğru açma), notaların doğru sesler ve ritimlerle seslendirilmesi, eserin armonisinin ve yapısının anlaşılması, ajilite, artikülasyon, ton kalitesi, gürlük işaretlerine uyma, kuvvetli ve zayıf zamanlara dikkat etme konularını gözden geçirerek düşünme önceki öğrenmelerde yer alan konulardır. Bu noktalar ders başında ve ders boyunca yeniden vurgulanmıştır.

İstenen içeriğin sunulması (uyaranı sunma) amacıyla, ders öğretim elemanı parçaları çalarak, öğrencilere ulaşılacak performansı örneklemiştir. Derste çalışılan ilk parça Duvernoy'un 'Do Majör etüdü'dür. Bu parçada yukarıda belirtilen önce öğrenilmiş becerilere ek olarak yeni öğrenilecek beceri, paralel hareketle yazılmış dizi seslerinden oluşan hızlı pasajları çalarken her iki elin parmaklarının ayn anda eşit olarak tuşlara inmesi ve dayanıklılık elde etmedir. Bu beceri parçadaki ayırt edici özelliktir. Dersin diğer parçası Alwyn'in 'The Sun is Setting' isimli parçasıdır. Bu parçadaki ayırt edici özellikler cantabile legato bir tuşeyle çalma, legato pedalı sesleri dinleyerek kullanma ve etkisini dinleme, melodi çizgisi hangi partideyse o partideki sesleri ön plana çıkarma, bir elle kuvvetli çalarken diğer elle hafif çalma, sesleri tasavvur ederek (benzetmeler hayal ederek) çalma, farklı ses renkleri elde etme becerileridir. Öğrencilere parçanın ayrıntılı tanımlanmasinda ABRSM'den (2012b, s.45) yararlanılmıştır. 
Öğrenme rehberliği sağlama amaciyla öğrencilere içerikte belirtilen beceriler ders öğretim elemanı tarafından teker teker sözel olarak ifade edilmiş ve çalarak gösterilmiştir. Öğrencilerin zihninde şablon oluşturabilmeleri için bu modellemeyi izlemeleri istenmiştir.

Öğrencilerden, performansın ortaya konması ve geliştirilmesi amacıyla parçalarını çalarak sunmaları istenmiştir. Böylece öğrencilere kendi kendilerine, arkadaşları ve ders öğretim elemanı ile birlikte öğrenmeleri için olanak sağlanmıştır.

Öğrencinin performansındaki doğruluğu onaylamak ve gerekirse düzeltme yapmak üzere ders öğretim elemanı ve diğer öğrenciler tarafından sürekli dönüt verilmiştir.

Öğrencilere performanslarını sunma ve dönüt alma imkânı verilmesiyle kendilerini değerlendirmeleri istenmiştir. Ayrıca öğrenciler 8 haftalık bir ders sürecinden sonra son performanslarını değerlendirme amacıyla çalıştıkları bu parçalardan dönem sonunda ders öğretim elemanı tarafından yapılan sinava girmişlerdir.

Zihinsel ve motor becerileri tutma ve transfer etme amaciyla öğrencilere daha önce öğrenme rehberliği sağlama, performansı sunma ve dönüt verme sırasında uygulamalar ve değerlendirmeler yapılmıştır. Öğrencilerden hafta içi çalışmalarını gruptaki diğer farklı çalışma arkadaşlarıyla çalışarak ortamlarını farklılaştırmaları istenmiştir. Yine her hafta ders başında farklı arkadaşlarıyla grup çalışmasına katılmışlardır. Öğretim dönemi sonunda öğrenciler, ders öğretim elemanı tarafından yapılan son performanslarını değerlendirme sınavına alınmışlardır. Ayrıca daha sonra bir komisyon önünde de parçalarını sunmuşlar ve bu komisyon tarafından da değerlendirilmişlerdir.

\section{Çalışma Grubu}

Dokuz öğretim olayına dayalı olarak planlanan piyano derslerinin işbirlikli yöntem kullanılarak yapılmasına yönelik yürütülen bu eylem araştırmasına beş kız öğrenci katılmıştır. Bu öğrenciler Marmara Üniversitesi Atatürk Eğitim Fakültesi Müzik Eğitimi Ana Bilim Dalında öğrenim gören ve ders öğretim elemanının iki yıldır ders yaptı̆̆ı öğrencilerdir. İkinci sınıfa devam eden bu öğrenciler grup çalışmasına katılmaya gönüllü olduklarını bildirmişlerdir. 


\section{Veri Toplama Araçları}

Öz Değerlendirme Formu: Her ders sonunda öğrencilerin o dersteki kendi performanslarını değerlendirmeleri için, dersin öğretim elemanı tarafından oluşturulan öz değerlendirme formu verilmiştir. Öz değerlendirme formunda yer alan 23 önerme dersin hedeflerine uygun olarak derste gerçekleştirilmesi beklenen becerilere yönelik ifadelerden oluşmuştur. Öz değerlendirme formunda 'notaları doğru ses ve ritimlerle çalma', 'kuvvetli ve zayıf zamanlara dikkat ederek çalma', 'sesleri tasavvur ederek çalma' gibi maddeler yer almıştır. Öğrencilerden her beceriyi gerçekleştirme durumlarını dörtlü derecelendirmeli (Hiç, Bazen, Çoğunlukla, Her zaman) bir ölçek üzerinde işaretlemeleri istenmiştir. Öz değerlendirme formunda ayrıca "Bugünkü derse yönelik düşünceleriniz nelerdir?" açık uçlu sorusu sorularak öğrencilerin dersi kendi ifadeleri ile değerlendirmeleri de sağlanmıştır.

İşbirlikli Öğretim Yöntemine Yönelik Düşünceler Anketi: Ders sürecinin başında öğrencilere işbirlikli öğrenme yöntemini nasıl yürütecekleri hakkında bilgi verilmiştir. Bu bilgiler ışığında yöntem hakkında neler düşündüklerini öğrenmek amacıyla öğretim elemanı tarafından oluşturulan açı uçlu dört soruyla görüşleri alınmıştır. Soruların tasarlanmasında işbirlikli çalışmanın en başında, öğrencilerin kendilerine anlatılan işbirlikli çalışmanın koşulları hakkındaki düşünceleri, varsa çekinceleri anlaşılmaya çalışıldığından dolayı sorular varsayımsal olarak sorulmuştur. Bu kapsamda şu sorular sorulmuştur: (1) Grup üyelerinin çalışmalar sonunda eşit başarı notu alacak olması size ne düşündürdü? (2) Çalışma arkadaşınızın size geribildirim verecek olması (eleştirmesi) sizi nasıl etkileyecek? (3) Ders sırasında grup içinde çalarken, çalışmanızı gruba gösterirken kendinizi nasıl hissedeceğinizi düşünüyorsunuz? (4) Grup çalışmasının olumlu ya da olumsuz tarafları sizce neler olacak?

İşbirlikli Ders Sürecini Değerlendirme Anketi: Ders süreci tamamlandığında, tüm sürecin farklı boyutlarıyla değerlendirilmesi amacıyla öğrencilere, dersin öğretim elemanı tarafından hazırlanan ve 13 açık uçlu sorudan oluşan bir anket verilmiştir. Ankette temel olarak, (a) işbirlikli yöntemin işleyişine, (b) öğrencilerin tüm süreç boyunca diğer arkadaşları hakkındaki (müzikal, teknik ve duygu durumları açısından) düşüncelerine ve (c) tüm ders- 
lerin sonunda öğretim elemanı tarafından yapılan sınavdaki kendi performanslarına yönelik değerlendirmeler yapmaları istenmiştir. İşbirlikli ders sürecinin değerlendirilmesine yönelik sorular 'olumlu bağlllık', 'bireysel sorumluluk', 'yüz yüze destekleyici etkileşim', 'sosyal beceriler' gibi boyutlara yönelik öğrenci görüşleri alınacak biçimde tasarlanmıştır. Bu kapsamda "Ders sırasında arkadaşlarınızın geri bildirimlerinin, eleştirilerinin sizi nasıl etkilediğini, ne gibi duygu ve düşünceler uyandırdığını olumlu veya olumsuz olarak değerlendirin."; "Grup üyelerinin eşit başarı notunu alması size ne düşündürdü?”; “Gruptaki arkadaşlarınız sizin çalışmalarınıza, çabalarınıza ne kadar katkı sağladı, motive etti? Ayrıca siz arkadaşlarınıza ne kadar katkı sağladınız"; "Gruptakilerle sosyal ilişkileriniz olumlu veya olumsuz yönde farklılaştı mı?" gibi sorular sorulmuştur.

Son Performans Değerlendirme Formu: Ders süreci tamamlandığında öğrencilerin performanslarının belirlenmesinde son performans değerlendirme formu kullanılmıştır. Form, ders hedefleri doğrultusunda teknik, müzikal, zihinsel ve sunum becerilerini içerecek şekilde ders öğretim elemanı tarafından hazırlanmıştır. Teknik beceriler, duruş-oturuş-beden dengesi, elparmak-kol hareketleri, hızlı pasajlarda dayanıklılık elde etme, tuşeye her iki elle eşit dokunuş, artikülasyon, ifadeli bir ses kalitesi geliştirme becerilerini; müzikal beceriler, ifadeli çalma, sesi yansitabilme, ses üzerinde denetim, anlamı ifade etme becerilerini; zihinsel beceriler, tonun, nota değerlerinin ve seslerin doğru okunması, tempo bütünlüğü, parçalardaki armoninin ve müzik biçiminin kavranması becerilerini ve sunum becerileri sunumun kendine güvenli ve ikna ediciliğini içermiştir. Bu kapsamda öğrenciler 100 puan üzerinden değerlendirilmişlerdir.

\section{Verilerin Toplanması ve Çözümlenmesi}

Tüm araştırma süreci boyunca öz değerlendirme formları, süreç başındaki, her ders sonundaki ve tüm süreç sonundaki açık uçlu sorulardan alınan duygu ve düşünceler orijinal ifadelerin alıntılanmasıyla veri olarak kullanılmıştır. Öz değerlendirme formlarında yer alan öğrenci değerlendirmeleri araştırmanın bulgular kısmında ilk ve son ders arasındaki farkı daha belirgin olarak ortaya koymak amacıyla sunulmuştur. Ayrıca öğretim elemanı ve komisyon tarafından yapılan değerlendirme sonuçları da öğrenci per- 
formans başarısının değerlendirilmesinde kullanılmıştır. Araştırma raporunda öğrencilerin gerçek isimleri yerine hayali isimler kullanılmıştır.

\section{Bulgular}

\section{İşbirlikli Öğrenme Yöntemi İle Yapılan Piyano Derslerine Yönelik Öğrenci Öz Değerlendirmelerine Yönelik Bulgular}

Araştırmada yapılan işbirlikli her piyano dersi sonrasında öğrencilerin kendi öz değerlendirmeleri, süreç sonunda yer alan ve öğretim elemanı tarafından yapılan son performans değerlendirme sınavındaki performanslarını değerlendirmelerine yönelik düşünceleri aşağıda verilmiştir.

\section{Ders Sonlarında Öğrencilerin Öz Değerlendirmelerine Yönelik Bulgular}

Araştırmada öğrenciler her dersin sonunda öz değerlendirme formlarına kendilerini değerlendirmişledir. Tablo 1'de öğrencilerin ilk ders (1. hafta) ve son ders (8. hafta) sonunda kendilerini değerlendirmeleri gösterilmiştir. Sonuçları daha çarpıcı gösterebilmek için ilk ve son hafta arasındaki öz değerlendirmeler verilmemiştir. Tablo 1'den anlaşıldığı gibi, ders hedefi olan teknik beceriler dikkate alındığında, öğrenciler el-parmak-kol hareketlerine yönelik gelişim gösterdiklerini ortaya koymaktadırlar. Özellikle el çatısı, dip oynar kemikten itibaren parmağın serbest hareketi, parmağın üç oynar kemiğinin çökmemesi gibi becerilerde öğrenciler son haftada kendilerine verdikleri puan değerini yükseltmişlerdir. Örneğin 9.önermedeki "Paralel hareketle yazılmış dizili sesleri çalarken her iki elin parmaklarının da aynı anda tuşlara inmesi" ifadesine yönelik olarak 5 öğrenciden dördünün son haftadaki becerilerinin ilk haftaya göre puan artışı sağladığı anlaşılmaktadır. Müzikal beceriler dikkate alındığında 15. önermedeki gürlük işaretlerine çoğunlukla uyduklarını ve daha da gelişme göstermediklerini düşündükleri görülmektedir. Ancak müzikal gelişmeye yönelik daha ayrıntılı ve somut ifadelerde geliştiklerini düşündükleri anlaşılmaktadır. Bu dikkate alındığında, kuvvetli ve zayıf zamanlara dikkat ederek çalma, şarkı söyleyen legato bir tuşeyle çalma, farklı partilerdeki melodi çizgisini ön plana çıarma gibi becerilerde öğrenciler, son haftada kendilerine verdikleri puan değerini yine yükseltmişlerdir. Örneğin, 19.önermedeki “Şarkı söyleyen legato bir 
tuşeyle çalma" ifadesinde 5 öğrenciden dördünün son haftadaki becerilerinin ilk haftaya göre puan artışı sağladığı görülmektedir. Zihinsel bir beceri olan 10. önermede öğrenciler kendilerini ilk haftadan itibaren çoğunlukla ve her zaman notaları doğru ses ve ritimlerle çaldıklarını belirtmişlerdir. Dolayısıyla burada bir sorun algilamamaktadırlar.

Tablo 1 dersin hedefleri açısından değerlendirildiğinde, öğrenciler ilk haftadan 8. haftaya kadarki süreçte piyano çalmada teknik, müzikal ve zihinsel becerilerin bir çoğunda kendilerini geliştirdiklerini düşünmektedirler.

Tablo 1. Öğrencilerin ilk (1) ve son (8) ders sonundaki öz değerlendirmeleri

\begin{tabular}{|c|c|c|c|c|c|c|c|c|c|c|}
\hline & \multicolumn{2}{|c|}{ Güliz } & \multicolumn{2}{|c|}{ Hale } & \multicolumn{2}{|c|}{ Buse } & \multicolumn{2}{|c|}{ Sena } & \multicolumn{2}{|c|}{ Kumru } \\
\hline & 1 & 8 & 1 & 8 & 1 & 8 & 1 & 8 & 1 & 8 \\
\hline Piyanoyu tam ortalayarak rahat bir vücutla oturma. & 4 & 4 & 4 & 4 & 3 & 4 & 4 & 4 & 2 & 3 \\
\hline Ellerin tuşlar üzerinde çatı (kubbe) biçiminde durması. & 3 & 4 & 3 & 4 & 3 & 4 & 3 & 4 & 3 & 3 \\
\hline $\begin{array}{l}\text { Parmakların her birinin dip oynaktan serbestçe kalkıp tuşa } \\
\text { inmesi (İkinci parmak bastığı anda birinci parmak tuşu bırakması). }\end{array}$ & 4 & 4 & 3 & 4 & 2 & 4 & 3 & 4 & 3 & 3 \\
\hline Parmakların üç oynağının da çökmemesi. & 3 & 4 & 3 & 4 & 2 & 4 & 3 & 4 & 3 & 3 \\
\hline $\begin{array}{l}\text { Parmak hareketleri sırasında bileğin aşağıda, esnek ve serbest } \\
\text { olması. }\end{array}$ & 3 & 4 & 3 & 4 & 3 & 3 & 2 & 3 & 3 & 3 \\
\hline Kolların omuz ekleminden itibaren serbest olması. & 4 & 4 & 3 & 4 & 4 & 4 & 3 & 4 & 3 & 3 \\
\hline $\begin{array}{l}\text { Dizilerde başparmağın üstten ve alttan geçişleri sırasında eli } \\
\text { döndürmeden o anda kolu hafifçe yana doğru açma. }\end{array}$ & 3 & 4 & 2 & 4 & 3 & 3 & 3 & 4 & 3 & 3 \\
\hline Dizinin tüm seslerini eşit olarak çalma. & 4 & 4 & 3 & 3 & 4 & 4 & 3 & 4 & 3 & 3 \\
\hline $\begin{array}{l}\text { Paralel hareketle yazılmış dizili sesleri çalarken her iki elin } \\
\text { parmaklarının da aynı anda tuşlara inmesi. }\end{array}$ & 1 & 3 & 1 & 3 & 3 & 3 & 2 & 3 & 1 & 3 \\
\hline Notaları doğru ses ve ritimlerle çalma. & 3 & 3 & 4 & 4 & 4 & 4 & 3 & 3 & 3 & 3 \\
\hline Doğru ritim değerlerini yapabilmek için sayarak çalma. & 3 & 4 & 3 & 4 & 3 & 4 & 4 & 4 & 3 & 3 \\
\hline Doğru parmak numaraları kullanma. & 4 & 3 & 3 & 4 & 3 & 3 & 2 & 3 & 2 & 2 \\
\hline Cümle sonlarında nefes alıp bilekleri gevşetme. & 4 & 4 & 4 & 4 & 4 & 4 & 3 & 4 & 2 & 3 \\
\hline Gürlük işaretlerine uyma. & 3 & 3 & 3 & 3 & 3 & 3 & 3 & 3 & 3 & 3 \\
\hline Kuvvetli ve zayıf zamanlara dikkat ederek çalma. & 2 & 3 & 3 & 4 & 3 & 3 & 3 & 4 & 3 & 3 \\
\hline $\begin{array}{l}\text { Melodi çizgisi hangi partideyse o partideki sesleri ön plana } \\
\text { çlkarma. }\end{array}$ & 2 & 4 & 3 & 4 & 3 & 4 & 3 & 4 & 3 & 3 \\
\hline Sesleri tasavvur ederek (benzetmeler hayal ederek) çalma. & 2 & 4 & 4 & 4 & 3 & 3 & 4 & 4 & 3 & 3 \\
\hline Üretilen sesleri dinleme. & 3 & 4 & 4 & 4 & 2 & 3 & 2 & 4 & 3 & 3 \\
\hline Şarkı söyleyen legato bir tuşeyle çalma. & 2 & 3 & 3 & 4 & 2 & 4 & 2 & 4 & 3 & 3 \\
\hline Legato pedalı uygun bir şekilde sesleri dinleyerek kullanma.* & 2 & 3 & 3 & 3 & 3 & 3 & 2 & 3 & 2 & 3 \\
\hline Bütünlüğü bozmadan (takılmadan) çalma. & 3 & 3 & 3 & 4 & 1 & 4 & 3 & 4 & 2 & 2 \\
\hline Bir elimle kuvvetli çalarken diğer elimle hafif çalma. & 2 & 3 & 4 & 3 & 4 & 4 & 3 & 4 & 2 & 3 \\
\hline Akor seslerini eşit ağırlıklarla çalma. & 2 & 4 & 4 & 3 & 3 & 4 & 3 & 4 & 2 & 3 \\
\hline
\end{tabular}

(1:Hiç, 2:Bazen, 3:Çoğunlukla, 4:Her zaman); *Legato pedalı uygun bir şekilde sesleri dinleyerek kullanma becerisi 4 . ders çalışılmaya başlandığından dolayı bu becerideki gelişim 4 ve 8 . dersler arasındaki gelişimi göstermektedir. 


\section{Öğrencilerin Süreç Sonundaki Son Performans Değerlendirme Stnavinda} Kendi Performanslarnı Değerlendirmelerine Yönelik Bulgular

Öğretim elemanı tarafından yapılan son performans değerlendirmesinde öğrencilerin kendi performansların değerlendirmeleri istenmiştir. Bu kapsamda öğrencilere "Piyano sınavınızdaki performansınızın niteliğini, sergilediğiniz güçlü ve zayıf yönler açısından değerlendiriniz." sorusu sorulmuştur. Öğrencilerin kendi performanslarını değerlendirmeleri şu şekilde olmuştur:

"Etütte hem nüans hem de tempo bakımından uyum içerisinde çaldığımı düşünüyorum. Parmaklarm atikti ve eklemler iyi hareket etti... Hem nüanslar hem de cümlelere, formlara geçişlerde o hissi oldukça iyi karşıya geçirmeyi hedefledim ve güzel bir performans sergiledim." (Hale)

"...teknik anlamda parmaklarm kalkmasına, çatı kurmaya ve atikliğe dikkat ettim... Çok hızh çalmamaya dikkat ettim... Hata yapmamak için bunu uyguladım... Nüanslara dikkat etmeye çalıştım..." (Güliz)

“...sınavımın iyi geçtiğini düşünüyorum... Parmak numaraların doğru çaldim... Bu beni çok motive etti..." (Kumru)

"...genel olarak iyi yorumladığımı ve çaldığımı düşünüyorum..." (Buse)

“...çok fazla heyecanlandım... Derste ve grup çalışmalarındaki performansımdan düşük çaldığımı düşünüyorum... Final sınavında çok daha fazla dikkat edeceğime inanıyorum..." (Sena)

Öğrencilerin, performanslarındaki parmak hareketlerindeki atiklik, el çatısı, hız gibi teknik öğelere ve nüanslara yaptıkları olumlu vurgular ve sınav performanslarından memnun oldukları anlaşılmaktadır. Bu sebeple öğrencilerin dersin hedeflerinde yer alan becerileri gerçekleştirdiklerini düşündükleri söylenebilir. Sadece Sena heyecanından dolayı ortaya koyduğu performansın, önceki derslerden düşük olduğunu belirtmekte ve komisyon karşısında yapılacak bir sonraki sınavda daha başarılı olacağına yönelik inancinı dile getirmektedir.

\section{Öğrencilerin Akranların Değerlendirmelerine Yönelik Bulgular}

Araştırma süreci sonunda grup üyelerinden akranlarını değerlendirmeleri istenmiştir. Grup üyeleri, akranlarının performanslarındaki teknik, zihinsel, müzikal beceriler vb. açısından değerlendirmeler yapmışlardır. Aşağıda öğrencilerin bu kapsamdaki görüşlerine yer verilmiştir. 
Öğrenciler, Hale'yi değerlendirirken “...hız kaygısı var, hız yüzünden parmaklarn tuşede kalıyor..."(Buse); Güliz'i değerlendirirken “...parmaklarının ve parçaya nasıl daha hızh hâkim olabildiğini en iyisinden en kötüsüne kadar gördüm..."(Sena) diyerek hız kavramına dikkat çekmişlerdir. Arkadaşlarının Kumru'yu değerlendirmelerinde ise “...parmaklarmmın esnekliği baştan görünüyordu... bunun gitgide daha fazla üstünde durdu... kendini geliştirmek için gayret gösterdi..."(Sena); “...parmaklarmm uzun olması ona parmak kaldırma konusunda büyük fayda sağlıyor... Tekniği çok iyi..."(Güliz) şeklindeki ifadelerle Kumru'nun parmak artikülasyonuna ve esnekliğine vurgu yapmışlardır. $\mathrm{Bu}$ ifadelerde hız, parmak artikülasyonu ve esnekliği gibi teknik beceriye yönelik değerlendirmeler göze çarpmaktadır.

Güliz'in tekniğini düzeltmeye yönelik motivasyonu arkadaşlarının dikkatini çekmiştir. Bunu, "...tekniğinde ufak tefek hatalar var, ama düzeltme gayreti de var..."(Kumru) şeklindeki bir ifadeyle arkadaşı belirtmiştir.

Öğrencilerin, “...Hale nüanslarn çok güzel kullanıyor..."(Güliz); “...Hale'nin müzikalitesi her geçen gün ilerliyor...”(Kumru); “...Buse'nin nüanslar çok iyi.."(Güliz);“...Busénin müzikalitesi güzel.."(Kumru); “...Buse'nin müzikal anlamda başarnl bir performansı var..."(Hale); “..Sena'nın müzikalitesi iyi.."(Kumru); “...Güliz'in müzikalitesi başarıll.."(Kumru) şeklindeki ifadelerinde birbirleri hakkında müzikal olarak olumlu değerlendirmeler yaptıkları ve müzikal beceri açısından gelişme gösterdiklerini belirttikleri görülmektedir. Öğrenciler birbirleri hakkında müzikteki nüansları kullandıklarını düşündüklerini söyleyebiliriz.

Güliz, “...Sena metronomla çalışıyor ve oldukça dikkatli..." şeklindeki ve "...Buse metronomla çalıştı̆̆ için ritimleri çok iyi..." ifadelerinde metronomla çalışmanın önemini ortaya koymuştur. Arkadaşının ritimlerin doğruluğuna dikkat çekerek zihinsel bir beceriye vurgu yapmıştır.

Öğrenciler birbirlerinin genel performanslarına ve gelişimlerine yönelik olarak da ifadeler belirtmişlerdir. Örneğin, Sena “...Hale'ye hatasını söylediğim anda nasıl hemen üzerinde durduğunu ve düzeltmek için emek verdiğini görüyorum..." diyerek arkadaşına yaptığı geribildirimin dikkate alındığını ve işe yararlılığını ortaya koymaktadır.

Hale ise "...Güliz derslere çahısarak geldi ve sorumluluğunu hissederek bunları da performansina yansıtarak en güzel şekilde uyguladı. Hataların görüp düzeltmesi de onun gelişimini hızlandırdı..." diyerek arkadaşının gelişimini vurgulamaktadır. Yine Hale "...Sena hataların kısa zamanda fark edip hemen toparlayabildi. 
Sorumluluklarmm bilincinde olup derse hep çalısarak geldi ve performansinda hep gelişerek kendini geliştirdi..." şeklindeki ve “...Kumru hataların fark edip düzenli ve hızl bir şekilde uyguladı... Hem kendinin hem de grup çalışmasının olumlu yönde ilerlemesini sağladı..." ve "...Buse düzenli bir çalışma sistemi var ve bunu en iyi şekilde hem bize hem de kendine katkı sağlayarak yansıttı." şeklindeki ifadelerinde gruptaki çalışma sorumluluğuna ve bunun da grubun başarısına katkısını vurgulamaktadır.

Öğrencilerin değerlendirmelerinde geçen ifadelerden hareketle birbirlerine yönelik olarak hangi boyutlarda değerlendirme yaptıkları Tablo 2'de verilmiştir.

Tablo 2. Öğrencilerin akranların dĕgerlendirdikleri boyutlar

\begin{tabular}{|c|c|c|c|c|c|c|}
\hline & \multicolumn{6}{|c|}{ Değerlendirilenler } \\
\hline & Ad & Buse & Güliz & Sena & Kumru & Hale \\
\hline \multirow{5}{*}{ 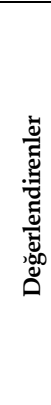 } & Buse & & & & & Hız (-) \\
\hline & Güliz & $\begin{array}{l}\text { Nüans } \\
\text { Ritim (+) }\end{array}$ & & Ritim (+) & $\begin{array}{l}\text { Artikülasyon } \\
(+)\end{array}$ & Nüans (+) \\
\hline & Sena & & $\mathrm{Hiz} \mathrm{(+)}$ & & Esneklik (+) & $\begin{array}{l}\text { Geribildi- } \\
\text { rimlerden yarar- } \\
\text { lanabilme }(+)\end{array}$ \\
\hline & Kumru & $\begin{array}{l}\text { Müzikalite } \\
(+)\end{array}$ & $\begin{array}{l}\text { Motivasyon (+) } \\
\text { Müzikalite }(+) \\
\end{array}$ & Müzikalite (+) & & Müzikalite (+) \\
\hline & Hale & $\begin{array}{l}\text { Müzikalite } \\
(+)\end{array}$ & $\begin{array}{l}\text { Çalışma } \\
\text { sorumluluğu }(+) \\
\text { Geribildirimlerden } \\
\text { yararlanabilme }(+)\end{array}$ & $\begin{array}{l}\text { Çalışma } \\
\text { sorumluluğu } \\
(+)\end{array}$ & $\begin{array}{l}\text { Kendi hataları- } \\
\text { nı fark etme }(+) \\
\text { Gruba katkı } \\
\text { sağlama }(+)\end{array}$ & \\
\hline
\end{tabular}

(+): Olumlu değerlendirme, (-): Olumsuz değerlendirme

Öğrencilerin birbirlerine yönelik yaptıkları değerlendirmelerle, yapıcı ve performanslarını geliştirici çeşitli boyutlara değindikleri anlaşılmaktadır. Öğrencilerin ifadelerinden, birbirlerinin öğrenmeleri ve gelişimleri hakkında düşündükleri ve katkı getiren davranışların neler olduğuna yönelik vurgu yaptıkları görülmektedir. Öğrenciler, teknik, zihinsel ve müzikal becerilere yönelik birbirlerinin gelişimlerine dikkat çekmişlerdir. Elde edilen bu verilerden, öğrencilerin birbirlerini değerlendirme sürecinin bireysel olarak kendilerinin ve grubun performansına olumlu katkılar sağladığını düşündüklerini söyleyebiliriz. 


\section{Öğrencilerin Öğretim Elemanı ve Komisyon Tarafından Yapılan Son Per-} formans Değerlendirmesine Yönelik Bulgular

8 haftalık ders süreci tamamlandığında öğrenciler ara sınav notlarını oluşturacak olan ve ders öğretim elemanı tarafından yapılan bir son performans değerlendirme sınavına alınmışlardır. Bu sınav, işbirliğini sağlamada gerekli olan grup ödülünü öğrencilerin alıp alamayacağını ortaya koyacağından önem taşımaktadır. Öğretim elemanının son performans değerlendirmesinden bir hafta sonra, öğrenciler iki kişilik (ders öğretim elemanı sınavda yer almış ancak bu değerlendirme sürecine katılmamıştır) bir komisyon önünde de ayrıca bir performans değerlendirme sınavına girmişlerdir. Öğrencilerin öğretim elemanı ve komisyon tarafından yapılan son performans değerlendirmeleri Tablo 3'de verilmiştir.

Tablo 3. Öğretim elemanı ve komisyonun öğrencilerin son performanslarına yönelik değerlendirmeleri

\begin{tabular}{|c|c|c|c|c|c|c|}
\hline Beceriler* & $\mathrm{PD}^{* *}$ & Güliz & Hale & Buse & Sena & Kumru \\
\hline \multirow{2}{*}{ Teknik } & ÖEPD & 85 & 80 & 85 & 85 & 85 \\
\hline & KPD & 80 & 85 & 85 & 85 & 85 \\
\hline \multirow{2}{*}{ Müzikal } & ÖEPD & 85 & 90 & 90 & 85 & 85 \\
\hline & KPD & 85 & 95 & 90 & 90 & 85 \\
\hline \multirow{2}{*}{ Zihinsel } & ÖEPD & 85 & 90 & 90 & 90 & 85 \\
\hline & KPD & 90 & 90 & 90 & 90 & 90 \\
\hline \multirow{2}{*}{ Sunum } & ÖEPD & 85 & 95 & 90 & 90 & 90 \\
\hline & KPD & 90 & 95 & 90 & 90 & 90 \\
\hline \multirow{2}{*}{$\begin{array}{l}\text { Başarı puanı } \\
\text { ortalaması }\end{array}$} & ÖEPD & 85 & 88,75 & 88,75 & 87,5 & 86,25 \\
\hline & KPD & 86,5 & 91,25 & 88,75 & 88,5 & 87,5 \\
\hline
\end{tabular}

*Becerilere ait içerik yöntem bölümünde verilmiştir. ${ }^{* *}$ PD:Performans değerlendirme; ÖEPD: Öğretim elemanı performans değerlendirme; KPD: Komisyon performans değerlendirme

Tablo 3'de görüldüğü gibi, ders öğretim elemanı tarafından yapılan son performans değerlendirme sinavında gruptaki tüm öğrencilerin dersin hedeflerini gerçekleştirerek benzer başarı seviyesine ulaştıkları saptanmıştır. Öğretim elemanı tarafından yapılan bu değerlendirme ile öğrencilerin öz değerlendirmeleri arasında tutarlılık olduğu anlaşılmaktadır. Öğrenciler bu 
süreçte ortak amaç ve ödül için çabalarını birleştirmeyi başardıklarından son performans değerlendirme sinavı sonucunda ders öğretim elemanı tarafından öğrencilere eşit başarı puanı verilmiştir. Buna göre en düşük puan alan öğrencinin puanı olan 85 başarı puanı tüm öğrencilere ara sınav başarı puanı olarak verilmiştir. Bu puan Marmara Üniversitesi sınav yönetmeliğindeki 100'lük başarı notuna göre BA (İyi-Pekiyi) harfli başarı notuna karşıllk gelmektedir.

Komisyon tarafından bir hafta sonra yapılan performans değerlendirme sınavında da tüm öğrencilerin benzer başarı seviyesine ulaştıkları Tablo 3 'de görülmektedir. Komisyon sınavı sonuçları hem öğrencilerin performansların bir kez daha sunup değerlendirilmeleri hem de ders öğretim elemanının yaptı̆̆ı değerlendirmenin teyit edilmesi açısından önemlidir.

\section{Piyano Derslerinde Kullanılan İşbirlikli Öğrenme Yönteminin Başlıca Koşullarına Yönelik Öğrencilerin Görüşlerine Dayalı Bulgular}

Araştırmada piyano derslerinde öğrencilere uygulanan işbirlikli yöntemin gerçekleşmesini sağlayan koşullar olan 'olumlu bağlllık', 'bireysel sorumluluk', 'yüz yüze destekleyici etkileşim', 'sosyal beceriler', 'grup sürecine yansıma' boyutlarına yönelik düşünceleri, ders süreci başlamadan önce ve süreç sonunda yapılan anketlerle ortaya konulmuştur. Bu kapsamda süreç öncesinde İşbirlikli Öğretim Yöntemine Yönelik Düşünceler Anketi ve süreç sonunda ise İşbirlikli Ders Sürecini Değerlendirme Anketi'nden elde edilen bulgular sentezlenerek aşağıda verilmiştir.

\section{Olumlu Bağlılık}

Öğrencilere işbirlikli çalışma süreci başlamadan önce işbirlikli çalışmanın gereği olan olumlu bağlılık anlatıldıktan sonra; olumlu bağlılığa yönelik olarak görüşlerinin ne olduğu sorulmuştur ve bazı öğrencilerin düşünceleri aşağıda verilmiştir:

"Grup üyelerime güveniyorum. Hepimizin fazlasıyla çalşıp hep birlikte hak ettiğimiz notu alacağımızı düşünüyorum. Ĕ̆er alamazsak, bir arkadaşımız çalamadığ için grup üyeleri düşük alırsak bu tabii ki bizim için iyi olmaz. Ama grup çalışmasının ne kadar ciddi bir şey olduğunu anlamamıza yardımcı olur."(Sena)

"Hepimizin ayn oranda gayret göstereceğinin belirtisi olduğu için bu bizim daha çok çalışmamıza sebep olacak yani bence gayet olumlu" (Güliz) 
"Ĕ̆er gerçekten grup olarak verimli bir çalışma yapıp, herkes üzerine düşen çalışma çabasını sorumlulukla yerine getirirse benim için problem yaratmaz." (Hale)

Verilen bu cevaplardan grup üyelerinin başarılı olmak için grubun başarılı olması gerektiğine inandıkları ve bunun önemini anladıkları anlaşılmaktadır. Ancak içlerinden bazılarının çekinceleri olsa da sonunda grup olarak bu işin içinden çıkmaları gerektiğinden birbirlerine yardım ederek ve çalışarak çözeceklerini düşünerek kendilerini rahatlatmışlardır. Örneğin Kumru başlangiçtaki "Kimi daha iyi kimi daha kötü kimi de orta seviyede arkadaşım için elimden geleni yaparm ama o sorumsuzsa çalışmıyorsa bunun faturası da bana kesilmemeli diye düşünüyorum... Bu bir bakıma güzel bir şey! Çünkü kötü olan ve eksiği olan arkadaşlarmm kendi yüzünden düşük almasını istemez ve çalışır..." şeklindeki ifadesinde çekincesini dile getirse de, dersler tamamlandıktan sonra "...güzel bir başarı yakaladığııızı düşünüyorum..." şeklindeki ifadesinden arkadaşlarıyla beraber ortaya çlkardıkları başarıyı vurgulamıştır.

Aynı şekilde Buse'nin de "Açıkçası hem sağlıklı hem de sağlıksız buluyorum. Sağlıkh oluşu; her grup üyesinin diğerlerini geriye çekmemek adına kendini çalışmaya adayacağın düşünüyorum. Sağlıksız oluşu; eğer tek bir grup üyesi bile çalışmaz ise grubu puan olarak geriye çekecek ve sonuçta belli bir yaşa gelmiş olan bütün üyelerimize çalışması adına baskı yapamayız... Her grup üyesinin diğerlerini geriye çekmemek adına kendini çalışmaya adayacağını düşünüyorum..." şeklindeki açıklamasıyla grup çalışmasına yönelik başlangıçta olumlu inancının yanında bir şüphe duyduğu görülüyor. Ancak son dersteki “...grup arkadaşlarımın hâkimiyeti yerinde... Herkes sorunsuz çalabilir ve ilerleyebilir... Arkadaşlarımdan ve kendimden meтnunum..." şeklindeki ifadesiyle grup başarılarına yönelik olumlu bir yaklaşım geliştirdiğini göstermektedir.

Güliz'in "...umarım grup arkadaşlarımı olumsuz etkilemedim..." ve aynı şekilde Sena'nın "...umarım arkadaşlarımı bu grup çalışması boyunca olumsuz etkilememişimdir..." şeklindeki ifadelerinden alacakları ortak grup ödülü için sorumluluk duydukları görülmektedir.

Başlangıçta olumlu bağlllığa yönelik şüpheleri olan öğrenciler olsa da işbirlikli öğrenme süreci boyunca kendi başarılarının herkesin başarısına etki edeceğini anladıkları ve böylece bu sorumluluk içinde çalıştıkları ve bir grup bilinci geliştirdikleri söylenebilir. 


\section{Bireysel Sorumluluk}

Araştırmada yapılan işbirlikli piyano derslerinde bireysel sorumluluğun oluşup oluşmadığını ortaya koymak amacıyla, gruptaki öğrencilere arkadaşlarının, onların performanslarını değerlendirmelerinin ve geri bildirimlerinin onları nasıl etkilediği sorulmuştur ve öğrencilerin bu konudaki düşünceleri aşağıda verilmiştir:

“...Özellikle parça esnasında arkadaşlarımın bir yandan beni yönetmesi parçamı bölse de o esnada yaptı̆̆ım hatalar hemen düzeltmeme yarar sağladı... Arkadaşlarıma yaptığım eleştirilere bizzat ben de dikkat etmeye çalıştım... Parçaya hâkimiyetim gelişti. Parmak kaldırmalarım, nüanslarım çatı biçiminde çalmam ve arkadaşlarımın hatalarımı anında düzeltmeye çalışması benim parçayı daha iyi çalmamı să̆ladı..." (Sena)

"...hızh değil yavaş çalışınca parmaklarm daha iyi olduğunu gösterdim..." (Kumru)

“... Arkadaşlarımm beni eleştirmesi olumlu yönde etkiledi. Yanlışlarımı daha hızh düzelttim... Daha dikkatli çalıştım. Hatalarımı onlar söylediği için kendimde görebilme şansim oldu..." (Hale)

"...bizi daha çok geliştirdiğini ve kendi göremediğimiz hatalar görmemizi să̆ladığını düşünüyorum... Çalarken her zaman daha özenli çalmamı sağladı... Arkadaşlarım yapamadığım yerleri bana çalarak ve göstererek öğrenmemi kolaylaştırdı. Grup çalışmasıyla, olduğundan daha çok çalıştım... Ben de arkadaşlarımı motive ettiğimi düşünüyorum... Yapamadıkları veya anlamadıkları yerleri anlattı̆̆ımı düşünüyorum..." (Güliz)

“...arkadaşlarımın derste çalmasını izlerken çalışmalarda dikkatli olmam gerektiğini çünkü notaya daldı̆̆ımda bir takım teknik hataların ortaya çıktı̆̆ını gördüm..."(Buse)

Öğrencilerin verdikleri cevaplardan kendi ve birbirlerinin performanslarına yönelik çıarımlar yaptıkları ve bunun da gelişimlerine katkı yaptığını vurguladıkları görülmektedir. İlk çalışmalarda tedirginlik yaşadıklarını aşağıdaki ifadelerle belirtmelerine rağmen çalışmaların ilerleyen haftalarında bu olumsuz düşüncelerin geçtiği görülmektedir.

“...her an birisi eleştirecek bir şey bulacak ve eserimi bölecek diye diken üstündeydim... esere veya etüde başladığımda bölünmesi veya eleştirilmesi hoşuma gitmiyor. ...dikkatim dağıllyyor ve demoralize oluyorum. Ama eser bittikten sonra yapılan eleştirileri dikkate alıyorum. Arkadaşlarımı izlerken arkadaşımın eksiklerini gör- 
düm... Kendi çalı̧mamda dikkat ettim... Aynı eksik bende varsa düzeltmeye çalı̧ttm..." (Kumru)

"...grupta çalarken ilk başlarda tedirgin olsam da, daha verimli bir çalşma sergileyip bu tedirginliğim azald. Grup çalışmalarında kendimi iyi hissettim... bu düzene uymak biraz zaman alsa da birbirimizin yanlışlarm görüp, uyarn uygulamaya dökmek konusunda başarı sağladık..." (Hale)

“... İlk zamanlar heyecanliydım. Ancak sonradan grup arkadaşlarıma alıştım ve daha rahat hareket ettim. Hatta onlarm beni dinlemesi hoşuma gitti ve bunu zevkle yaptım... Onlarm iyi yaptığı şeyleri örnek alıp kendimde uygulamaya çalıştım. Bu da gelişmemde fayda sağladı. Olumsuz bir tarafı olduğunu düş̈̈nmüyorum..."(Güliz)

Dolayısıyla öğrencilerin belirttikleri görüşlere göre önceleri birbirlerini değerlendirmelerinin onlara endişe verdiği ama giderek bu endişenin yerini olumlu duygulara bıraktığı anlaşılmaktadır. Öğrenciler grupta çalmanın ve değerlendirilmenin kendilerini geliştirdiğini fark etmişlerdir. Böylece öğrencilerin işbirlikli çalışmanın gereği olan bireysel sorumluluk anlayışını giderek geliştirdikleri anlaşılmaktadır.

\section{Yüz Yüze Destekleyici Etkileşim}

Araştırmada yapılan işbirlikli piyano dersleri sırasında yüz yüze destekleyici etkileşimin gerçekleşip gerçekleşmediğini ortaya koymak amaciyla, gruptaki öğrencilere birbirlerinin çalışmalarını ne kadar özendirdikleri veya birbirlerinin işini ne kadar kolaylaştırdıkları sorulmuştur. Öğrencilerin bu konudaki düşünceleri aşağıda verilmiştir:

“...onların çalması, çalış biçimi dinlemelerime göre biraz etkisi oldu. Çünkü örneğin etütte bazı ölçüleri farklı duyumlarda dinlemek kendi performansıma da etkisi oldu... Arkadaşlarımı çalışmaya motive ettiğimi hem de edildiğimi düşündüm... Birbirimize destek vererek yanlışlarmizı en kolay ve en uygun biçimde düzeltip sergileyebileceğimizi kolaylaştırdı."(Hale)

“...birbirimizi dinlediğimiz için daha dikkatli ve odaklı çaldı̆̆ımızı düşünüyorum... eleştirildiğimizde yanlışlarımızı kahıı olarak düzeltiyoruz..."(Güliz)

“...grup çalışmalarımızda bildiğimiz her şeyi birbirimizle paylaştık...”(Kumru)

Öğrencilerin ifadelerinden birbirlerini motive ettikleri, paylaşım içinde oldukları ve birbirlerini özendirerek işlerini kolaylaştırdıklarını vurguladıkları görülmektedir. Buradan da öğrencilerin yüz yüze etkileşim içinde olduklarını söyleyebiliriz. 


\section{Sosyal Beceriler}

Araştırmada yapılan işbirlikli piyano dersleri sırasında öğrenciler arasındaki sosyal becerilerin gelişip gelişmediğini ortaya koymak amacıyla, gruptaki öğrencilere birbirleriyle olan iletişimlerinin nasıl olduğu sorulmuştur ve öğrencilerin bu konudaki düşünceleri aşağıdaki paragraflarda verilmiştir. Aynı zamanda grubun başarısına katkıda bulunmak ve birbirleri arasındaki sosyal becerilerin geliştirilmesi amacıyla öğrenciler özetleyici, denetleyici, özendirici, gözlemci, bağ kurucu gibi çeşitli roller almışlardır.

Grubun ne derece iyi çalıştı̆̆ını değerlendirerek gözlemci rolünü üstlenen Kumru“...arkadaşlarımın bilip benim bilmediğim bir parmak numarası var mı diye düşünmüyorum... çünkü grup çalışmalarımızda bildiğimiz her şeyi birbirimizle paylaştık..." diyerek aralarındaki olumlu iletişimi vurgulamıştır. Aynı şekilde Güliz de buna "...birbirimize daha yakın olduk..." şeklindeki ifadesiyle katılmaktadır. Güliz aynı zamanda grupta yeni öğrenilenlerle önceki öğrenilenler arasında bağ kurarak bağ kurucu rolündedir. Güliz “... Grup içerisinde herkesin bir işlevinin olması bizi bir bütün yapıyor ve bir araya gelince birbirimizi tamamlyyoruz, bu bizi daha iyi bir grup yapryor..." diyerek rollerin kendilerine olan kazanımlara vurgu yapmaktadır.

Aralarındaki iletişimi Sena "...eleştiriye açık bir hale geldik ve birbirimizin hataların düzeltmeye herkes yardımcı oldu. Tam bir grup çalışması meydana geldi... Kimse birbirine alınmadı, herkes eleştiriye açıkt..." şeklinde ifade etmiştir.

Öğrencilerin ifadelerinden grubun ekip ruhu ile çalışarak birbirleriyle olan iletişimlerinde olumlu kişilerarası ve sosyal beceriler geliştirdikleri hissedilmektedir. Örneğin; Sena “...ben özendirici görevindeydim. Hafta içi onları sürekli çalışmaya ittim. Hataların anında söyledim, onların da beni dikkate aldığın düşünüyorum..." diyerek arkadaşlarına liderlik ettiğini göstermektedir. Aynı şekilde Güliz de "...arkadaşlarımı motive ettiğimi düşünüyorum... Yapamadıkları veya anlamadıkları yerleri anlattı̆̆ımı düşünüyorum..." diyerek onlara yol gösterirken önderlik ettiği görülmektedir. Hale ise “...arkadaşlarımın gelemediği haftalarda derste yaptığımı uygulamaları, nasıl çalışması gerektiğini grup arkadaşıma da aktararak dersten geri kalmaması ve uyumlu bir şekilde derse hazırlıkl gelmeyi amaçladık..." diyerek aralarında bir çalışma bağı kurduklarını, birbirlerinin eksiklerini tamamladıklarını belirtmiştir. Buradan da birbirlerine karşı uyum içinde güven inşa ettikleri ve liderlik becerileri sergiledikleri anlaşılmaktadır. 
Ders sonlarında grubun ulaştığı sonuçları yeniden kısaca açılayarak özetleyici rolünü üstlenen Buse hem kendi görevini hakkıyla yaptığını hem de diğer (özendirici rolündeki) arkadaşının rollünün hakkını verdiğini belirtmiştir.

“... Sena'nın özendiriciliği başarılıydı... Özetleyici olarak benim ders sonu yaptığım yorumlar dersin bize artılarını gösterdi..." (Buse)

Grup üyelerinin öğrenilenleri tam olarak açıklayıp açıklayamadığını sınayan denetleyici rolünü üstlenen Hale “...gayet iyi bir uygulama olduğunu düşünüyorum. Böylelikle farklı açılardan kendimizi gördük, sorumluluklarımızı hissettik ve bunu uygulamaya dökünce de ortaya güzel grup çalışmalar meydana geldi." diyerek rollerin önemini vurgulamıştır. Sena da benzer vurguyu şu şekilde belirtmiştir: "Herkes aldı̆̆ı rolleri başarıyla tamamladı. Ders sonunda o haftada yaşadığımı tüm zorlukları, kolaylikları ve dersteki performansımızı değerlendirdik. Bu bana göre olumlu bir şeydi."

Öğrencilerin ifadelerinden grup içinde birbirlerini çalışmaya özendirme, çalışmalarını kontrol etme, bütünü oluşturmaya yönelik gayret sarf ettikleri anlaşılmaktadır. Dolayısıyla öğrencilerin işbirlikli çalışmanın gereği olan karşılıklı güvene dayalı ve samimi bir iletişim içinde olduklarını ve olumlu sosyal beceriler geliştirdiklerini söyleyebiliriz.

\section{Grup Sürecine Yansima}

Öğrenciler her dersin sonunda o günkü çalışmaya yönelik değerlendirme yapmışlardır. Bu değerlendirmeler, öğrencilerin kendi öğrenmeleri üzerine düşünüp düşünmediklerini, hangi davranışların gruba katkı getirdiğini ya da değişmesi gerektiğini anlayıp anlamadıklarını, birbirlerinden aldıkları geribildirimlerin etkili olup olmadığını ortaya koymak amacıyla yapılmıştır.

Yapılan değerlendirmelerden öğrencilerin kendi öğrenmeleri üzerinde düşündükleri, arkadaşlarının yaptıkları hataların üzerinden kendi yanlışlarını fark ettikleri ve birbirlerine verdikleri dönütlerin etkili olduğunu anladıkları anlaşılmaktadır. Aşağıda bu düşünceleri belirttikleri ifadeler yer almaktadır:

“Çok verimli bir ders olduğunu düşünüyorum. Çünkü grup çalşması yaparak yanlı̧larımızı daha rahat görüp, kısa sürede halletmeye çalıştık. Birbirimizin hatasını görerek aynı hatayı yapmamaya özen gösterdik." (Hale) 
“Bugünkü dersin diğer derslere göre verimli olduğunu düşünüyorum. Çünkü hatalarımı ve doğrularımı daha iyi fark ettiğgimi anladım." (Sena)

"Güzel ve eğlenceli bir ders oldu. Herkes hem eğlendi hem de verim aldı. Eksiklerimizi görüp kendimizi düzeltirken aynı zamanda arkadaşlarımızda gördüğümüz hataları da düzelttik." (Kumru)

Öğrenciler dikkatlerinin derse çekilmesi konusunda da ifadeler belirtmişlerdir. Kendi çalma sırasını beklerken arkadaşının çalmasını izleme kendi çalarken neler yapacağını düşünmeyi gerektirdiğinden sürekli bir konsantrasyonu dinamik tutmaktadır. Örneğin Güliz “Çalarken birbirimizi dinleyip yorum yapmamı kendimizde olan ve farkına varamadığımı yanlışları düzeltmemizde büyük katkı sağlıyor, grup çalışmasıyla birbirimizden güç alıyoruz, daha dikkatli çalmam gerekiyor..." derken derse yönelik dikkatini ortaya koymaktadır. Buse de "Sürekli uyarılmak tetikte olmayı beraberinde getiriyor. Bu da çalışmayı olumlu etkiliyor. Uyarılma sürekli olmalı." diyerek dikkatinin çalı̧̧ma üzerinde olduğunu belirtiyor. Buse ayn zamanda yapılan geribildirimlerin dikkat çekmede etkili olduğunu "Arkadaşlarıma yapmış olduğum uyarılardan olumlu dönüt aldım. Bu uyarılarım arkadaşlarımın da ilgisini çekti ve daha verimli bir çalma ortamı yarattık." diyerek belirtmiş ve birbirlerine yaptıkları geribildirimlerin çalışmalarına olan katkısını vurgulamıştır. Öğrencilerin performansları hakkında ne yapabildiklerini göstermek açısından birbirlerine bilgilendirerek dönüt vermeleri onları memnun etmiştir.

Ders sonu değerlendirmelerden öğrencilerin kendi eksiklerinin neler olduğunu belirledikleri ve neleri nasıl geliştireceklerine yönelik olan fikir yürütmeleri aşağıdaki ifadelerde görülmektedir.

"Çalarken birbirimizi dinleyip yorum yapmamı kendimizde olan ve farkına varamadığımı yanlışlan düzeltmemizde büyük katkı sağlıyor. Grup çalışmasıyla birbirimizden güç alıyoruz. Bunun dışında daha dikkatli çalmam gerekiyor. Odaklanmamın daha iyi olması lazım, notalara daha çok çalışmahyım."(Güliz)

"Arkadaşlarım bugün eksiklerimi söyleyerek yaptığım yanlışı düzeltmeme daha yardımcı oldu. Birbirimize yardım ederek parçayı daha doğru bir şekilde çalmamızı hedefledik. Yanlışımı düzeltince daha güvenle çaldım. Parçaya hâkim olabilmek için daha çok konsantre olmam, yavaş ve düzenli çalısmam gerekmektedir. Parçayı metronom eşliğinde eş tempoda çalışı, nüanslara ve parmak geçişlerine dikkat etmeliyim. Sol el parmaklarımı daha atik kaldırarak parçanın hem geçişlerini hem de istenilen notayı daha iyi duyurmuş olurum."(Hale) 
Yukarıda verilen Hale'nin ifadesinde ve aşağıdaki ifadelerde görüldüğü gibi öğrencilerin hedef ve alt hedeflere yönelik farkındalık içinde oldukları ve onlardan beklenilenleri gerçekleştirmek için gayret ettikleri anlaşılmaktadır.

"Benim eksiklerim en çok parmaklarımı kaldırma ve eklemlerime dikkat etmem gerektiği konusunda ve buna dikkat edeceğim."(Sena)

"Etüdü geçen haftaya göre daha düzenli ve gürlük işaretlerine dikkat ederek olması gerektiği gibi çaldım. Diğger eserde biraz daha sol el yumuşaklığına dikkat edebildim."(Hale)

Sena "Çalarken grup arkadaşlarımın sürekli uyarıda bulunması, hatalarımı çalma esnasında düzeltmek için çaba göstermeleri beni parçamı çalarken olumlu etkiliyor. Benim arkadaşlarıma yaptı̆̆ım eleştirileri de onlarm göz önünde bulundurduğunu düşünüyorum. Çalışırken arkadaşlarımın eleştirilerini hatırlayarak bunlara uymaya çalışacağım." diyerek üyeler arasındaki iletişimin etkisini vurgulamış ve birbirlerine yönelik geri bildirimlerin gelişimlerine katkıda bulunduğunu belirtmiştir.

Sena'nun değerlendirmelerinde yer alan "...git gide arkadaşlarımda ve bendeki ilerlemeleri açıkça gözlemleyebiliyorum" ve Kumru'nun "birbirimizi uyarıyoruz ve bu bizi daha da ilerletiyor." şeklindeki ifadesiyle çalışmalardaki gelişmeyi gördükleri anlaşılmaktadır. Yine Kumru'nun değerlendirmesinde yer alan "Beraber çalışma ciddiye alındı̆̆ında çok güzel sonuçlar elde ediliyor... Dikkate alınan eleştiriler ve güzel dinleme sonucu başarımı her hafta katlanıyor." şeklindeki ifadesinden çalışmalarda elde ettikleri gelişmeden memnun oldukları anlaşılmaktadır.

Güliz "Grup arkadaşlarımın hepsi bu hafta çok iyi çalı̧̧ıştı. Ben ise sadece eserde sorun yaşadım. İstenildiği gibi çalışmamam grup arkadaşlarımı da zorladı. Haftaya daha iyi çalışıp geleceğim." derken kendine yönelik öz eleştiride bulunmakta ve kendi çalışması için plan yapmaktadır. Hale de "Eserde biraz emin olmadığımı için akor seslerini basarken zorlandık. Biraz daha çalışı haftayaki derse esere verdiğimiz duygu, nüans ve tartım hataları daha dikkatli olacak." diye belirtirken; Buse "bütün üyelerde panik hakimdi. Özellikle bağlanması gereken akorlarda. Kuvvetli ve zayıf zamanlara yönelik çalışmalar yapılmalı." diye belirtmekte ve Sena ise "Metronoma uyarak çalışacağım." diyerek yapılması gerekenlere dikkatlerini vermektedirler. 
Derste öğretmen tarafından modellenerek gösterilen bir elle kuvvetli çalarken diğer elle hafif çalma ile ilgili sunulan yeni bir içeriğe yönelik olarak öğrenciler düşüncelerini şu şekilde belirtmişlerdir:

"Yeni bir egzersiz öğrendik ve bu egzersiz bize çalışmalarımızda sağ el ve sol eli iyi ayırt edebilmemize yarayacak... Hafif ve kuvvetli çalmayı geliştirmek için yeni bir sistem öğrendik ve bu hafta içinde uygulayacağız." (Sena)

"Fortissimo ve pianissimo çalışmalarma yoğunluk vermek eser içerisindeki solo yürüyüşlere yardımcı olacaktır." (Buse)

"Gürlük, yumuşaklık, bağlı çalma gibi terimleri eser üzerinde uyguladık. Daha verimli bir grup çalışması yapabilir ve diğger haftaya daha hazır ve düzenli bir performans sergileyebiliriz." (Hale)

$\mathrm{Bu}$ ifadelerden öğrencilerin verilen içeriğin farkında olduklarını ve bu içerikteki kendi bilişsel öğrenmeleriyle ilgili karar aldıkları görülmektedir.

Öğrencilerin son derslerinin değerlendirmelerine bakıldığında performansa yönelik memnuniyet göze çarpmaktadır. Güliz "Bu hafta herkes etüdü ve eseri tam olarak çıkarmış geldi.."diyerek; Hale "Bugünkü dersimizde grup çalışmamız daha verimli geçtiği için yanlışlarımızı daha hızl düzeltip parçaları bütünlüğ̈̈ne inebildik. Etüdü geçen haftaya göre daha düzenli ve gürlük işaretlerine dikkat ederek olması gerektiği gibi çaldım. Diğer eserde biraz daha sol el yumuşaklığına dikkat edebildim." diyerek; Buse "Değiştirmeye değer bir şey yok. Grup arkadaşlarımm hâkimiyeti yerinde... Herkes takllmadan sorunsuz çalabilir ve ilerleyebilir. Arkadaşlarımdan ve kendimden memnunum." diyerek grubun olumlu davranışlara ulaştığını belirtmektedirler.

\section{Sonuç ve Tartışma}

Araştırmanın amacı, işbirlikli öğrenme yöntemlerinden birlikte öğrenme tekniği kullanılarak ve Gagne'nin dokuz öğretim olayına göre planlanarak yapılan piyano derslerinin işleyişinin ve işbirlikli öğrenme yöntemine yönelik öğrencilerin görüşlerinin belirlenmesidir.

Araştırma süreci boyunca öğrencilerden toplanan verilerden ve süreç sonundaki sınav değerlendirmesinden, Gagne'nin dokuz öğretim olayına göre planlanarak grupla yapılan piyano derslerinde kullanılan işbirlikli öğrenme yöntemlerinden birlikte öğrenme tekniğinin işleyişinin başarıyla gerçekleştiği anlaşılmaktadır. Piyano derslerinde hedeflenen teknik, müzikal, zihinsel ve sunum becerilerinin geliştirilmesine yönelik olarak öğrenciler elde ettikleri başarıyı öz değerlendirmelerinde ve derslerde birbirlerine 
verdikleri geribildirimlerde ortaya koymaktadırlar. Süreç sonunda ders öğretim elemanı ve ayrıca iki kişilik bir komisyon tarafından yapılan ve dersin hedeflerine göre belirlenen ölçütleri içeren son performans değerlendirme sınavlarında da öğrenciler başarılı olmuşlardır.

Kocabaş (1995), araştırmasında işbirlikli öğrenme tekniklerinin müziğe ilişkin tutumları, müziksel alan bilgileri, müziği öğrenme stratejileri ve blok flüt çalma becerileri üzerinde geleneksel öğrenme tekniklerinden anlamlı derecede olumlu yönde etkili olduğunu bulmuştur. Bilen ve Ün Açıkgöz de (2019) yaptıkları araştırmada işbirlikli öğrenme yöntemi, nota ile öğrenme ve kulaktan notalı öğretim yöntemlerine göre şarkı söyleme becerilerinin geliştirilmesinde anlamlı düzeyde daha etkili olduğunu belirtmişlerdir. Sağer ve arkadaşları (2015) yaptığı çalışmada, işbirlikli öğrenme yaklaşımına dayalı uygulamaların, öğrencilerin çoksesli solfej alan başarısını olumlu yönde ve yüksek düzeyde etkilediği sonucuna ulaşmışlardır. Ancak Öztürk ve Kalyoncu (2018) ise araştırmalarında işbirlikli öğrenme yönteminin, Müzik Teorisi ve Müziksel Yazma (Dikte) başarısının artmasında etkili olmadığını; buna karşın, Müziksel İşitme Okuma ve Yazma (MIOY) dersine yönelik genel kaygının azalmasında istatistiksel açıdan anlamlı fark yaratacak şekilde etkili olduğunu bulmuştur. Nacakçı (2011) ise araştırmasında, deney grubuna uygulanan işbirliğine dayalı öğrenim yönteminin kontrol grubuna oranla dikte (müziksel yazma) ve aralık duyma becerilerinin kazandırılmasında daha etkili olduğu tespit etmiştir. Ayrıca deney grubundaki öğrencilerin çalışma süresince derse ilgilerinin artı̆̆ı, bireysel olarak birbirleriyle karşılaştırması yapılmadığı için kendine güven ve sorumluklarını artırarak küme başarısını ön plana aldıklarını da belirtmiştir.

Mevcut ve daha önce yürütülen araştırmaların sonuçları genel olarak değerlendirildiğinde, müzik eğitiminde farklı bilgi ve becerilerin geliştirilerek başarının sağlanmasında işbirlikli öğrenme yöntemlerinin etkili ve kullanılabilir olduğu söylenebilir.

Araştırmada, işbirliğine dayalı öğrenmenin beş temel unsuru olan olumlu bağllıık, yüz yüze destekleyici etkileşim, bireysel sorumluluk, kişilerarası veya sosyal beceriler ve grup sürecine yansıma boyutlarında işleyişin etkili bir şekilde gerçekleştiği belirlenmiştir. Dolayısıyla piyano derslerinin işbirlikli öğrenme yöntemiyle yürütülmesinin, öğrencilerin birbirlerinin öğrenmesi için gayret göstererek olumlu bağgllık geliştirmelerine sebep olmada; grubun başarısında payları olduğunu bilmelerinin bireysel sorumluluk sahibi 
olmaları gerektiğini anlamalarını sağlamada etkili olduğu düşünülmektedir. Ayrıca işbirlikli öğrenme yöntemi kapsamında öğrencilerin sürekli bir paylaşım içinde birbirlerini motive etmelerinin yüz yüze destekleyici etkileşim içinde olmalarına ve süregelen bu iletişimin de sosyal beceriler geliştirmelerine katkı sağladığı söylenebilir. İşbirlikli öğrenme yöntemi kapsamında derslerde yapılan öz ve akran değerlendirmelerinin grup sürecine yansımaya sebep olarak öğrencilerin kendi öğrenmeleri üzerine düşünmelerini ve kararlar almalarını sağladığı da ifade edilebilir.

Kocabaş ve Erbil (2013) de araştırmalarında, sınıf öğretmenliği öğretmen adaylarının Müzik Öğretimi dersinde uygulanan işbirlikli öğrenme yöntemi ve uygulamaları konusundaki görüş ve düşüncelerini belirlemiş ve şu sonuca ulaşmışlardır. Öğretmen adaylarına göre, işbirlikli öğrenmenin planlama ve uygulama aşamasında diğer grup çalışmalarından farkını ortaya koyan özellikleri yüz yüze etkileşim ve sosyal beceriler, grup dayanışması ve birlikte hareket etmek, grup ürününü ortaya çıkarmak, olumlu bağımlılıktır. Yine öğretmen adaylarına göre, müzik dersinin zor ve ayrı bir yetenek gerektiren bir ders olduğuna ilişkin önyargıları ve başarısız olma kaygıları işbirlikli öğrenme yönteminin 'her öğrenciye eşit başarı imkânı' ilkesi sonucunda kaybolmakta, birlikte çalışmayı ve öğrenmeyi sağlamaktadır. Olumlu sınıf iklimi, özgüven ortaya çıkarma, müzik yeteneğini geliştirme, farklı yorumlamalara olanak verme, yetenekleri ortaya çıkarma, derse ilgiyi arttırma, farklılıkları kabullenme ve saygı duyma işbirlikli öğrenmenin olumlu çıktılarındandır. Ritim araçlarını kullanabilme becerisi, deşifre etmeyi kolaylaştırma, öğrenci merkezli bir yöntem olması, dinlenmeyi sağlaması, anında dönüt ve düzeltme, çalma becerilerini geliştirme, doğayı daha iyi tanıma diğer olumlu etkileridir.

Sonuç olarak Gagne'nin dokuz öğretim olayına göre planlanarak grupla yapılan piyano derslerinde kullanılan işbirlikli öğrenme yöntemlerinden birlikte öğrenme tekniğinin dersin hedeflerini gerçekleştirmede ve geliştirmede etkili olduğu anlaşılmıştır. Ayrıca olumlu bağlılık, yüz yüze destekleyici etkileşim, bireysel sorumluluk, kişilerarası veya sosyal beceriler ve grup sürecine yansıma boyutlarında da beklenen yararları sağlayarak, öğrenciler arasında öğrenmeye, işbirlikli çalışmaya, sağlıklı iletişim becerileri geliştirmeye, kendilerini ve akranların değerlendirmeye ve bu değerlendirmelerden yararlanmaya yönelik beceriler geliştirdiği düşünülmektedir. 
Araştırmanın nitel araştırma modelleri kapsamında bir eylem araştırması olarak desenlenmesinden hareketle, araştırma sonuçlarından genelleme yapılamayacağı göz önünde bulundurulmalıdır. Ayrıca çalışma grubunun beş kişi ve tüm katılımcıların kız öğrencilerden oluşuyor olması da sonuçların değerlendirilmesinde dikkate alınmalıdır. Araştırmadaki bu sınırlılıklardan hareketle, takip eden çalışmalarda daha farklı grup sayılarıyla ve cinsiyet yapılarıla (sadece erkeklerin olduğu veya karma gruplarla) araştırmalar sürdürülebilir. Bu araştırma kapsamındaki hedefler 5 kişilik bir grupla başarıyla gerçekleştirilmiştir. Ancak grupla yapılacak piyano dersleri için en uygun grup büyüklüklerinin kestirilebilmesi için daha yüksek ve daha düşük sayılı gruplarla da benzer araştırmaların yapılması önerilebilir. 


\title{
EXTENDED ABSTRACT
}

\section{The Functionality of Cooperative Learning Methodology in Piano Lessons Designed in Gagne's Instructional Theory}

\author{
Jale Deniz \\ Marmara University
}

Instrument training is usually done individually. However, when we look at the applications made towards instrument training, it is seen that there are trends towards group training as well as individual training practices. Examples of these orientations are group piano training (Hahn, 2019; Özalp and Özdemir, 2019; Tecimer Kasap, 2005). Group piano training was first started from the 1920s and 1930s. With the invention of electronic keyboards, group lessons became widespread (Hallam, 1998, p.253). When the research conducted in our country is examined, it is seen that the piano training performed in a group particularly in recent years has been applied at the level of music teacher candidates and conservatory students. As a result of an experimental study conducted with music education students of the Faculty of Education, Aydınl and Tecimer (2013) found that group piano training was more successful in developing the piano accompaniment and transpose skills of the students than individual piano training. As a result of the experimental research with students studying music at the faculty of education, Lehimler and Batıbay (2018) found that the artistic and functional piano skills of the students who were taught piano within a group were significantly better than the control group that took individual piano training. Acar (2019) revealed that the program conducted for the usability of music technologies in group piano training at the beginner level through an action research was functionally successful.

Performing individual or group training in instrument training is mutually supportive activities. Promoting group instrument learning makes benefits in achieving musical standards and achieving musical development (Ley, 2004, s. 9). 
There are many literature sources of the training of instruments in which master-apprentice relationships have been stated to traditionally lead to training (Çelik Nayır, 2018; Haşhaş, 2016; Izgi, Yazıcı and Kılıç, 2016). However, today, the development of both general and specific (music) contemporary training approaches (model, method, etc.) opens new horizons in the field of instrument training. However, the effectiveness of these training approaches must be planned and embodied specifically in the field. For example, Gagne's Instructional Theory offered a general framework for the training process, with nine training events. On the other hand, the importance of cooperative learning has increased with the expansion of constructivist learning understanding by taking part in instructional programs. For effective training, students can provide both learning guidance and feedback to each other by using cooperative learning structures in addition to these nine events of training (Driscoll, 2012, p.422). Thus these two approaches can be used effectively together.

The problem of this research is how Gagne's nine training events can be applied in piano lessons with the cooperative learning method. In line with this problem, the study aimed to determine the functioning of the piano lessons and the opinions of the students about this method by using the technique of learning together from cooperative learning methods and planning according to Gagne's Nine Events of Instruction. In line with this general-purpose, for determining the teaching method of the piano lessons, the answers to the following research questions were sought. (1) How are students' self-evaluations? (2) How do students evaluate their peers? (3) How are the final performance evaluations made by the students, the instructor, and the commission? (4) What are the opinions of the students regarding the basic conditions of cooperative learning (Positive interdependence, Individual accountability, Face-to-face promotional interaction, Social skills, Group processing) used in piano lessons?

The action research model, one of the qualitative research designs, was used in the research. An 8-week study consisting of two hours of lessons was conducted to demonstrate individual performance by working as a group. The lectures were planned on the basis of Gagne's Instructional Theory depending on his nine training events. At the same time, using the cooperative learning structures, students are allowed to provide each other with both learning guidance and feedback. 
The researcher played a role in this process as both the researcher and lecturer of the course. The study group consisted of 5 female students studying in the department of music education, Atatürk Faculty of Education, Marmara University. Data in the study were collected through self and peer evaluation forms, performance evaluation form, and an open-ended questionnaire.

Considering the data collected from the students during the research process and from the exam evaluation at the end of the process, it is understood that the operation of the learning together technique from the cooperative learning methods used in the group piano lessons, planned according to Gagne's nine training events, was successful. What is aimed at piano lessons is that students should demonstrate their success with their selfassessment and give feedback to each other in lessons to develop their technical, musical, mental, and presentation skills. The students were successful in the final performance evaluation exams at the end of the process, which were conducted by the course instructor and a two-person commission, and which included the criteria determined according to the course goals.

When the results of current and previous research (Bilen and Ün Açikgöz, 2019; Kocabaş, 1995; Nacakçı, 2011; Öztürk and Kalyoncu, 2018; Sağer et al., 2015) are evaluated in general, it can be said that the cooperative learning methods are effective and usable in improving different knowledge and skills in music education and achieving success.

In the study, it was determined that the five basic elements of cooperative learning including 'Positive interdependence', 'Face-to-face promotional interaction', 'Individual accountability', 'Interpersonal skills', and 'Group processing' were effectively realized. Therefore, it is thought that conducting piano lessons with cooperative learning method is effective in causing students to develop Positive interdependence by encouraging each other to learn and that knowing that they have a share individually in the success of the group is effective in making them understand that they should have individual accountability. Within the scope of cooperative learning method, it is also understood that motivating each other in a continuous sharing allows them to be in face-to-face promotional interaction. It can be said that this ongoing communication also contributes to the development of social skills. It can also be stated that self-and peer assessments made in courses 
within the scope of the cooperative learning method allow students to think and make decisions about their own learning that causes group processing.

As a result, it was understood that the technique of learning together from the Nine Events of Instruction methods used in group piano lessons, planned according to Gagne's Nine Events of Instruction, was effective in achieving the objectives of the course. It also provided the expected benefits in terms of positive interdependence, face-to-face promotional interaction, individual accountability, interpersonal skills, and group processing, thus, it is thought to develop skills of students for learning, working cooperatively, developing healthy communication skills, evaluating themselves and their peers and benefiting from these evaluations.

\section{Kaynakça / References}

ABRSM (2012a). Alwyn The Sun is setting. Piano exam pieces 2013\&2014 (Grade4). Score, içinde (s.8-9) England: The Associated Board of the Royal Schools of Music.

ABRSM (2012b). Alwyn the sun is setting. (S. Ellis cont.) Teaching notes on piano exam pieces $2013 \& 2014$ (Grade1-7). İcinde (s.45)England: The Associated Board of the Royal Schools of Music.

Acar, A.K. (2019). Müzik teknolojilerinin başlangıç seviye grup piyano eğitiminde kullanulabilirliğine yönelik öğretim programı önerisi: Midi piyano laboratuvar uygulamaları. (Yayımlanmamış yüksek lisans tezi). Uludağ Üniversitesi Eğitim Bilimleri Enstitüsü, Bursa.

Aydınlı, D. ve Tecimer, B. (2013). Grup piyano öğretiminin müzik eğitimi öğrencilerinin okul şarkılarını eşlikleme ve transpoze becerilerinin geliştirilmesine etkisi. Cumhuriyet Uluslararası Eğitim Dergisi, 2(2), 10-24.

Bilen, S. ve Ün Açıkgöz, K. (2019). İşbirlikli öğrenmenin şarkı söyleme becerileri üzerindeki etkisi. YYü Eğitim Fakültesi Dergisi, 16(1), 803-817.

Bradley, D. (ed). (t.y.). Tuneful graded studies. Rhythmical scales, agility for both hands Volume 3. İcinde [score, s.32-33] by Duvernoy, Bosworth, UK.

Çelik Nayır, Y. (2018). Güzel sanatlar liselerinde piyano eğitiminin teknik ve pedagojik açıdan incelenmesi. Yayımlanmamış yüksek lisans tezi. Haliç Üniversitesi Sosyal Bilimler Enstitüsü, İstanbul.

Driscoll, M. (2012). Öğretim süreçleri ve öğrenme psikolojisi. Ankara:Anı.

Efe, R., Hevedanlı, M., Ketani, Ş., Çakmak, Ö., ve Efe, H.A. (2008). İsbirlikli ö̆grenme teori ve uygulama. Ankara: Eflatun. 
Hahn, R.D. (2019). Reaching digital native music majors: Pedagogy for undergraduate group piano in the 21st century. Unpublished Doctoral dissertation, University of Missouri-Columbia.

Hallam, S. (1998). Instrumental teaching: A practical guide to better teaching and learning. Oxford: Heinemann.

Hallam, S. (2008). Music psychology in education. London: Bedford Way Papers.

Haşhaş, S. (2016). Bağlama öğretimi/öğreniminde geçmişten günümüze usta-çrak ilişkisi. İnönü Üniversitesi Kültür ve Sanat Dergisi, 2(2), 35-41.

İzgi Topalak Ş., Yazıı T., Kılıç I. (2016). Piyano öğretim elemanlarının başlangıç seviyesi piyano öğretimi uygulamalarına ilişkin görüşleri Abant İzet Baysal Üniversitesi Ĕ̆itim Fakültesi Dergisi, 16 (İpekyolu Özel Sayıs1), 2295-2309.

Johnson, A. P. (2015). Eylem araştırması el kitabı. (2. bs). (Y. Uzuner, M. Özten Anay Çeviri editörleri), Ankara: Anı Yayıncllik.

Johnson, D.W., Johnson, R.T., VE Holubec, E.J. (2016). İşbirlikli öğrenme el kitabı. A. Kocabaş (Çev. Ed.); A. Kocabaş, D. G. Erbil, T. Karaarslan (Çev.), Ankara, Pegem Akademi.

Kocabaş, A. (1995). İşbirlikli öğrenmenin blokflüt öğretimi ve öğrenme stratejileri üzerindeki etkileri. Yayımlanmamış doktora tezi. Dokuz Eylül Üniversitesi Sosyal Bilimler Enstitüsü, İzmir.

Kocabaş, A. ve Erbil, D.G. (2013). Müzik öğretimi dersinde işbirlikli öğrenme yönteminin kullanılması ve yaratıcılık üzerine öğretmen adaylarının görüşleri. International Symposium on Changes and New Trends in Education, November 2224, 2013 Konya, Turkey, Symposium Proceedings Book Volume I, 186-199.

Lehimler, E. ve Batıbay, D. (2018). Artistik piyano becerilerinin geliştirilmesinde grup piyano öğretiminin etkileri. Atatürk Üniversitesi Sosyal Bilimler Enstitüsü Dergisi, 22(Özel Say1), 2875-2887

Ley, B. (2004). The dynamics of group teaching in All together: Teaching music in groups. A. Marks (Ed.), The Associated Board of the Royal Schools of Music içinde (s.4-11), UK.

Nacakc, Z. (2011). Müziksel işitme okuma ve yazma dersinde işbirliğine dayalı öğrenmenin öğrencilerin başarılarına etkisi. E-Journal of New World Sciences Academy, 6(2), 180-186.

Özalp, U. ve Özdemir, G. (2019). Grup piyano eğitiminin öğrenci görüşleri çerçevesinde değerlendirilmesi. Eğitim ve Toplum Araştırmalan DergisilJRES, 6(2), 355372 . 
Öztürk, G. ve Kalyoncu, N. (2018). Müziksel işitme eğitiminde kullanılan işbirlikli öğrenme yönteminin öğrenci kaygı ve başarısına etkisi, Eğitimde ve Psikolojide Ölçme ve Değerlendirme Dergisi, 9(4), 356-375.

Saban, A. (2014). Öğrenme öğretme süreci (7. bs.). Nobel: Ankara.

Sağer, T., Gürpınar, E., ve Zahal, O. (2015). İşbirlikli öğrenme yöntemine dayalı uygulamaların çoksesli solfej alan başarısına etkisi. Hacettepe Üniversitesi Eğitim Fakültesi Dergisi, 30(1), 195-212.

Schunk, D.H. (2009). Alan bilgisi öğrenimi (çev. K. Celasun) (5. bs'dan çeviri; M. Şahin Çev. Ed.), Öğrenme teorileri: Eğitimsel bir bakış içinde (s. 406-451), Nobel: Ankara.

Tecimer Kasap, B. (2005). Amerika Birleşik Devletleri'nde grup piyano eğitimi. Gazi Üniversitesi Gazi Ĕ̆itim Fakültesi Dergisi, 25(3), 191-206.

Ün Açıgöz, K. (2008). Aktiföğrenme (10. bs.). Biliş̧: İstanbul.

Yıldırım, A. ve Şimşek, H. (2013). Sosyal bilimlerde nitel araştırma yöntemleri (9.Baskı). Seçkin: Ankara.

\section{Kaynakça Bilgisi / Citation Information}

Deniz, J. (2020). Gagne'nin öğretim kuramı temelinde yapılandırılmış piyano derslerinde işbirlikli öğrenme yönteminin işlevselliği. OPUS-Uluslararası Toplum Araştırmaları Dergisi, 16(31), 4097-4137. DOI: 10.26466/opus.680488 